\title{
The scolopendromorph centipedes (Chilopoda, Scolopendromorpha) of Tunisia: taxonomy, distribution and habitats
}

\author{
Nesrine Akkari', Pavel Stoev², John G.E. Lewis ${ }^{3}$ \\ I Research Unit of Biodiversity and Biology of Populations, Institut Supérieur des Sciences Biologiques \\ Appliquées de Tunis, Tunis, Tunisia 2 National Museum of Natural History, Sofia, Bulgaria 3 Somerset \\ County Museum, Taunton Castle, Taunton, Somerset, UK and Entomology Department, The Natural \\ History Museum, London, UK \\ Corresponding author: Nesrine Akkari (nesrineakkari@gmail.com)
}

Academic editor:MarzioZapparoli | Received3 October 2008 | Accepted4 November 2008 | Published9 November 2008

Citation: Akkari N, Stoev P, Lewis JGE (2008) The scolopendromorph centipedes (Chilopoda, Scolopendromorpha) of Tunisia: taxonomy, distribution and habitats. ZooKeys 3: 77-102. doi: 10.3897/zookeys.3.51

\begin{abstract}
The present paper provides a review of the composition, distribution and habitat preferences of the scolopendromorph centipede fauna of Tunisia. Five (sub)genera and 8 (sub)species have hitherto been reported from the country, of which two are of uncertain status. After a study of significant amount of new material collected in the period 2003-2008, 6 species, namely Scolopendra canidens Newport, 1844, S. morsitans Linnaeus, 1758, Cormocephalus gervaisianus (C.L. Koch, 1841), Otostigmus spinicaudus (Newport, 1844), Cryptops punicus Silvestri, 1896 and C. trisulcatus Brölemann, 1902, were found in the country. New illustrations and, where appropriate, brief descriptions of the species are given, along with an identification key for the Tunisian scolopendromorphs. Cryptops anomalans Newport, 1844, Scolopendra oraniensis Lucas, 1846 and S. cingulata Latreille, 1829 are excluded from the country's list since all previous records are most likely based on misidentifications. Cryptops trisulcatus and C. punicus are recorded for the first time from Tunisia and Libya, respectively. The taxonomic position of C. punicus is discussed and the species is transferred from the subgenus Trigonocryptops to Cryptops. Scolopendra morsitans scopoliana is synonymised under $S$. morsitans. S. canidens, O. spinicaudus and C. punicus are well adapted to arid and semidesert biotopes and have much wider ranges compared to the other three species which are restricted to the northern, more humid parts of the country. S. canidens is the only myriapod in Tunisia found in a pure sandy desert.
\end{abstract}

\section{Keywords}

Scolopendra, Cormocephalus, Otostigmus, Cryptops, deserts, oases, identification key, Tunisia, Libya 


\section{Introduction}

The scolopendromorph centipedes of Tunisia have never been studied intensively. Prior to Silvestri's (1896) paper "Una escursione in Tunisia..." only two species, Scolopendra oraniensis Lucas, 1846 and Scolopendra mediterranea var. africana Verhoeff, 1891 collected in the cities of Tunis and Gabes respectively [misspelled Ghades], had been recorded from the country (Pocock 1892, Verhoeff, 1891, Verhoeff 1893). After studying topotypic material of the latter, Silvestri (1896) proposed its synonymy with S. oraniensis. In the same publication he also recorded Cupipes (now Cormocephalus) gervaisianus (C.L. Koch, 1841) and Cryptops anomalans Newport, 1844 for Tunisia, and described a new variety, punicus, of C. anomalans. Verhoeff (1901) described Otostigma tunetanum from Tunis which Kraepelin (1903) later synonymized with Otostigmus spinicaudus (Newport, 1844). Kraepelin also reported S. morsitans scopoliana C.L. Koch, 1841 and S. canidens Newport, 1844, although he did not specify where exactly these species were collected. He disregarded the separate status of punicus. Attems (1902) reported Scolopendra morsitans Linnaeus, 1758 from Medjez-el-Bab in North Tunisia. A few years later, he (Attems 1908) also identified the myriapods amassed by Henri Gadeau de Kerville during his remarkable expedition to Kroumirie (NW Tunisia), confirming the occurrence in the area of C. gervaisianus and C. anomalans. Brölemann (1904) reported Scolopendra morsitans and S. canidens from several localities in Tunisia and was the first to summarize the information on the Myriapoda of North Africa, providing a checklist of all species known at that time (Brolemann 1921). He mentioned altogether 9 (sub)species of Scolopendromorpha for Tunisia, including Scolopendra cingulata Latreille, 1829, although, like Kraepelin, he did not mention any specific localities. In another paper (Brolemann 1928) he raised Cryptops anomalans punicus to full species rank and transferred it to the genus Trigonocryptops Verhoeff, 1906. In his monograph on Scolopendromorpha Attems (1930) excluded $S$. oraniensis and $S$. cingulata from the list of Tunisian species and probably being unaware of Brolemann's publication, regarded C. punicus as a synonym of C. anomalans. Studying a small collection of myriapods collected by Dr. Cloudsley-Thompson in Tunisia, Turk (1955) recorded S. canidens and S. clavipes C.L. Koch, 1847 from Jebel Cherchera, west of Kairouan. The same material was later referred to by CloudsleyThompson (1956). Dobroruka (1968) reported S. morsitans, S. canidens (incl. S. c. cyrenaica Verhoeff, 1908), and C. gervaisianus from several localities in Tunisia. Lewis (1969) recorded Scolopendra amazonica Bücherl, 1946, which is currently considered a junior synonym of S. morsitans (Würmli 1975, Koch 1983), from a mountain near Soukahas, Tunis, at 1000-1500 m elevation. This record from 1894 may refer to the Barbary state of Tunis rather than the city. This seems probable as there is no settlement with this name near Tunis, nor a mountain that high.

The taxonomic status and the distribution in the Mediterranean region of the species of $S$. canidens group were revised by Würmli (1980). Two of the subspecies, $S$. canidens oraniensis and S. canidens cretica Attems, 1902, were given full species rank, while some others including $S$. c. cyrenaica were synonymized. The author concluded 
that in Tunisia the group, which comprises also S. clavipes and S. dalmatica C.L. Koch, 1847 , is represented only by $S$. canidens. Recently, Zapparoli (2002), Zapparoli et al. (2004), Simaiakis and Mylonas (2008) mentioned Tunisia in their overviews of the world range of Scolopendra cingulata. The centipede fauna of the Italian islands Lampedusa, Linosa and Pantelleria, which are situated close to Tunisian coast, was studied by Zapparoli (1995). On Pantelleria, which is located approx. $70 \mathrm{~km}$ off the Tunisian coast he recorded C. punicus, C. trisulcatus Brölemann, 1902, and S. cingulata, while on the Pelagic islands Lampedusa and Linosa lying ca. $120 \mathrm{~km}$ off the coast $S$. canidens and C. punicus were found. CHILOBASE, the world catalogue of Chilopoda (Minelli 2006) lists the following taxa: C. anomalans, C. punicus, C. gervaisianus, $S$. oraniensis and $O$. spinicaudus for Tunisia.

The Tunisian scolopendromorph fauna comprises 5 (sub)genera and 8 (sub)species, of which, the occurrence of $S$. cingulata and $C$. anomalans needs confirmation. Almost all the remaining species are known from single outdated records, mainly from the northern, generally better prospected parts of the country (e.g. Kroumirie and Mogods regions). The scolopendromorph fauna of the arid, semidesert and desert regions in the central and southern parts of the country (e.g. the Tunisian Ridge, the Sahel, the plain of Kasserine, the Grand Erg Oriental and the coastal plain of Jeffara) remained virtually unknown as had the biology and ecology of all Tunisian species.

In the last five years abundant material of Scolopendromorpha collected in each of the four main bioclimatic zones of the country: Humid (Kroumirie and Mogods regions), Subhumid (Cap Bon Peninsula), Semiarid-Arid (Central Tunisia), Arid (meridian Tunisia, south of $36^{\text {th }}$ parallel) was accumulated and investigated. The aim of present paper is to put on record the results of the identification of this significant collection and to provide detailed information on the taxonomy, distribution, habitats and in some cases also the biology of scolopendromorphs in Tunisia. New illustrations based on the freshly collected material and a key are provided to facilitate the identification of the species.

\section{Material and methods}

Unless stated otherwise, the material treated herein has been collected by N.A. and P.S. during a month long collecting trip in Tunisia conducted in March 2008, and also in the course of individual excursions by the first author to different regions of the country in the period 2003-2008. Various types of habitats were prospected for scolopendromorphs: oak forests (Quercus suber, Q. faginea, Q. ilex), pine forest (Pinus halepensis), open habitats dominated by Stipa tenacissima, arid rocky planes with scattered palm trees, pure sandy and rocky deserts, coastal and mountainous oases dominated by palm trees (Phoenix dactylifera), etc. All the material was preserved in 70 or $96 \%$ ethanol and was shared between the Field Museum of Natural History, Chicago, National Museum of Natural History, Sofia and University of Tunis El Manar. Close up photos were taken under an Olympus SZH 10 research microscope with an Olym- 
pus Altra-20 colour camera, and were processed using the program Adobe Photoshop CS2. A complete chronological list of citations related to species occurrence in Tunisia is also provided. Morphological terminology follows Lewis et al. (2005).

Abbreviations: ad. $=$ adult, alt. $=$ altitude, Distr. $=$ District, ex. $=$ exemplar $/ \mathrm{s}$, juv. $=$ juvenile, N.P. $=$ National Park, subad. $=$ subadult.

\section{Species account}

\section{Order Scolopendromorpha Family Scolopendridae}

\section{Scolopendra canidens Newport, 1844}

Figs 1-7

Scolopendra dalmatica var. africana Verhoeff, 1891, Berliner entomologische Zeitschrift, 36: 69. Scolopendra mediterranea var. africana: Verhoeff 1893, Berliner entomologische Zeitschrift, 38:

319, fig. a.

Scolopendra oraniensis: Pocock 1892, Proceedings of the Zoological Society of London: 25. Scolopendra oraniensis: Silvestri 1896, Naturalista Siciliano, An. I, (Nuova Serie), 8: 150.

Scolopendra canidens: Kraepelin 1903, Mitteilungen aus dem Naturhistorischen Museum in Hamburg, 20: 248, fig. 157.

Scolopendra canidens and S. oraniensis: Brölemann 1904, Bulletin du Muséum d'Histoire Naturelle 6: 318 .

Scolopendra canidens and S. oraniensis: Brolemann 1921, Bulletin de la Société des Sciences

Naturelles du Maroc, I (3-6): 104-105.

Scolopendra canidens canidens: Attems 1930, Das Tierreich, 54: 36.

Scolopendra canidens and S. canidens oraniensis: Brolemann 1932, Bulletin de la Société d'Histoire Naturelle d'Afrique du Nord, 23 (2): 52.

Scolopendra canidens canidens and S. clavipes: Turk 1955, Annals and Magazine of Natural History, ser. 12, vol. 8: 281.

Scolopendra canidens canidens and S. clavipes: Cloudsley-Thompson 1956, Annals and Magazine of Natural History, ser. 12, vol. 9: 328.

Scolopendra canidens canidens and S. canidens cyrenaica: Dobroruka 1968, Revue de Zoologie et de Botanique Africaines 78(3-4): 203.

Scolopendra canidens: Würmli 1980, Sitzungsberichte der Österreichischen Akademie der Wissenschaften, 189: 346, Abb. 10, 26.

Scolopendra canidens: Lewis 1985, Bijdragen tot de Dierkunde, 55 (1): 128, fig. 11, map 2.

Material examined. 1 juv., Sousse, N35 $49.57 /$ E10 38.19 , alt. $11 \mathrm{~m}, 17.2 .2004$; 1 ad., same locality, 22.3.2004; 1 juv., Le Kef, N36º11.44/ E0844.39, alt. 623 m, 24.10.2003; 2 ex., Sfax, Agareb Steppe, N3444.13/ E10³2.15, alt. 68 m, olive orchard, under stones, 25.11.2003; 1 juv., Mahdia Distr., Bekalta, N35³7.06/ E1 1 ${ }^{\circ} 00.44$, alt. $12 \mathrm{~m}$, border of agricultural land, under stones, 30.10.2003; 1 ad., 3 juv., Sousse 
Distr., Sidi Khalifa, N36 $15.18 / \mathrm{E} 10^{\circ} 26.48$, alt. $1 \mathrm{~m}$, open area, 17.2.2004; 2 ex., Monastir, N35\%46.43/ E10 49.48, alt. 6 m, 22.12.2004; 1 ex., Sousse Distr., Bou Ficha, $\mathrm{N} 36^{\circ} 17.55 / \mathrm{E} 10^{\circ} 27.30$, alt. 6 m, 22.3.2005; 1 ex., Hergla, N36 01.53/ E10 30.37, alt. 3 m, coast, 23.3.2005; 2 ad., 2 subad., Sidi Bouzid Distr., Bou Hedma N.P., N34³0.28/ E09 35.46 , alt. $574 \mathrm{~m}$, semi dry area dominated by Acacia raddiana, 20.3.2006; 1 subad., Nabeul Distr., Korba, N36³4.36/ E1051.02, alt. 3 m, coast, 12.11.2006; 12 ex., Sfax Distr., Kerkennah Island, Chargui, N3442.34/ E1 $1^{\circ} 09.14$, alt. 3 m, sandy open area, with scattered palm trees, under stones, 20.3.2007; 2 ad., Kebili, Fatnassa Oasis, May 2007; 1 ad., Zaouit El Hareth Oasis, 20.5.2007; 1 ad., Makthar, 12.5.2005; 2 juv.,
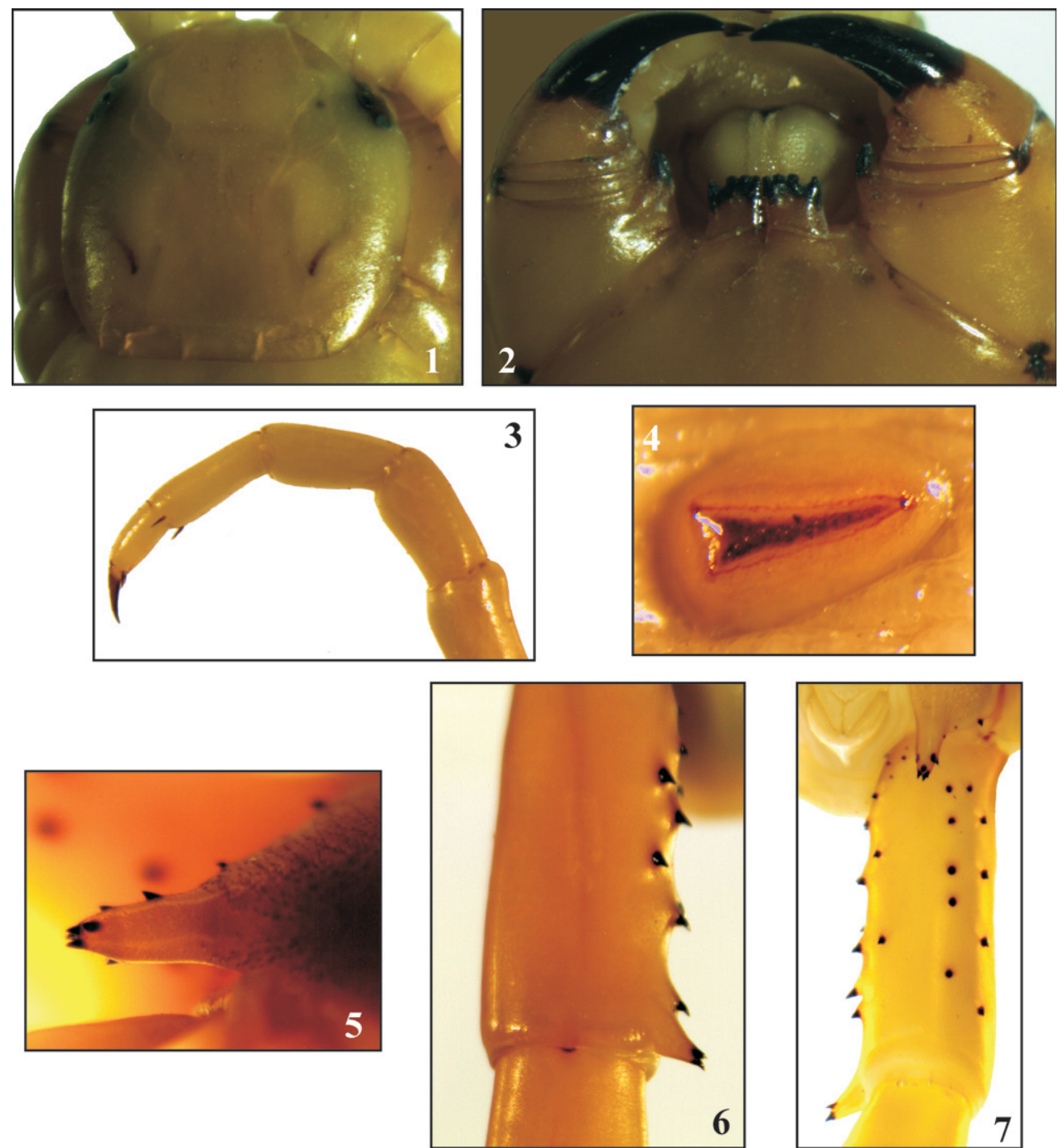

Figs I-7. Scolopendra canidens: 1 - head plate; 2 - forcipular coxosternum and forcipules; 3 - leg 1; 4 - spiracle; 5 - coxopleural process, lateral view; 6-7 - prefemur of ultimate leg, dorsal and ventral views, respectively. 
Kairouan Distr., Oueslatia, Aouinettes, 3.3.2005; 1 ex., Djerba Island, N3352.09/ E10 50.42, alt. 10 m, 10.7.2003; 1 ex., Bizerta Distr., Ichkeul N.P., N3709/ E95, maquis with Olea europaea, Pistacia lentiscus and Smilax aspersa, 8.2.2004; 6 juv., Kairouan Distr., $6 \mathrm{~km}$ of Oueslatia, N35 $51.785 /$ E09 30.972 , alt. $581 \mathrm{~m}$, sparse olive trees, Roman ruins, bush, open area, stone debris, under stones, 6.3.2008; 1 ad., 1 juv., Sbeitla, $30 \mathrm{~km} \mathrm{NW} \mathrm{Kasserine,} \mathrm{inside} \mathrm{the} \mathrm{ruins} \mathrm{of} \mathrm{the} \mathrm{ancient} \mathrm{Roman} \mathrm{town} \mathrm{of}$ Sifetoula, under stones, 7.3.2008; 4 ex., Kasserine Distr., Chambi N.P., surrounding of the park's guest house, N35 $10.139 / \mathrm{E} 08^{\circ} 40.486$, alt. $950 \mathrm{~m}$, sparse trees, bush, Pinus halepensis, under stones, 7.3.2008; 1 ad., 3 juv., same locality, alt. 950-1000 m, Pinus halepensis, Stipa tenacissima, Thuya, under stones, logs and leaf litter of Pinus halepensis, 8.3.2008; 1 juv., inside Chambi N.P., N35¹1.901/ E08 39.505, alt. 1291 $\mathrm{m}$, Pinus halepensis, Quercus ilex, Stipa tenacissima, slope, under stones and leaf litter, 9.3.2008; 1 ad., Chambi peak and its surroundings, N35 ${ }^{\circ} 12.285 /$ E0 $08^{\circ} 40.653$, alt. 1500-1540 m, Pinus halepensis, Quercus ilex, Stipa tenacissima, under stones and leaf litter, 9.3.2008; 1 ad., 1 juv., Gafsa Distr., Jebel Bou Ramli, N34³0.877/ E08 39.731, alt. $512 \mathrm{~m}$, deserted rocky plain at the foot of the mountain, scattered trees, Opuntia and palm trees, under stones, 10.3.2008; 1 ad., Kebili Distr., Tombar, $6 \mathrm{~km}$ of Kebili, $\mathrm{N} 33^{\circ} 43.463 / \mathrm{E} 08^{\circ} 54.349$, alt. $14 \mathrm{~m}$, oasis, palm trees, under stones, 12.3.2008; 2 ad., Kebili Distr., 10-20 km of Douz towards Matmata, N3327.647/ E09 11.466 , alt. 92, pure desert, sand, under stones, 12.3.2008; 5 ad., 3 juv., Gabes Distr., Matmata, N33 $32.450 / \mathrm{E} 09^{\circ} 59.054$, alt. $384 \mathrm{~m}$, arid biotope, shrubs and stones, under stones, 12.3.2008; 2 ad., 1 juv., Gabes Distr., Matmata, N3332.450/ E0959.055, alt. $384 \mathrm{~m}$, arid biotope, shrubs and stones, under stones, 13.3.2008; 2 ad., Tataouine Distr., surroundings of Tataouine city, N32 $55.506 / \mathrm{E} 10^{\circ} 26.913$, alt. $293 \mathrm{~m}$, arid biotope, slope, stones, scattered trees of Pinus (planted), under stones, 13.3.2008; 3 ad., same district, Ksar Ouled Soltane, N32 $2^{\circ} 7.281 /$ E10 30.784 , alt. 453 m, arid biotope, rocks, stones, close to the village, under stones, 14.3.2008; 1 ad., Tataouine Distr., between Chenini and Douiret (mainly around Douiret), N32 $2^{\circ} 1.090 /$ E10 16.900 , alt. $425 \mathrm{~m}$, arid biotope, close to the road, under stones, 14.3.2008; 1 juv., Mahdia Distr., Chebba ( $37 \mathrm{~km}$ south of Mahdia), N35 $12.865 /$ E1 $1^{\circ} 06.344$, alt. $2 \mathrm{~m}$, polluted suburban area close to the beach, under stones, 15.3.2008; 5 ad., Mahdia Distr., Mahdia City, Touristic area, N35 $32.796 / \mathrm{E} 11^{\circ} 01.662$, alt. $0 \mathrm{~m}$, scattered palm trees and shrubs close to the road, polluted area not far from agricultural land, under stones, 16.3.2008; 1 ad., same locality, beach, sand, approx. 50-80 m from the water line, under stones, 16.3.2008; 4 ad., 2 juv., same district, surroundings of Ksour Essef (17 $\mathrm{km}$ of Mahdia), N35 $24.824 /$ E1 $0^{\circ} 58.026$, alt. $59 \mathrm{~m}$, olive trees (Olea europaea), grass, stones and shrubs, under stones, 16.3.2008; 2 ad., 3 juv., Siliana Distr., Jebel Bargou, $5 \mathrm{~km}$ of Bargou (road Bargou - Oueslatia), N36 05.775/ E09 37.347, alt. $571 \mathrm{~m}$, Quercus, Olea, shrubs, under stones, 28.3.2008; 1 ad., 3 juv., same mountain, $50 \mathrm{~km}$ of Oueslatia (road Bargou - Oueslatia), N36 06.941/ E09³9.392, alt. 512 m, sparse olive trees, rocks, under stones, 28.3.2008; 8 ad., 6 juv., Zaghouan Distr., Jebel Mansour, close to Sidi Aouidet village, N36 $12.307 /$ E0 $9^{\circ} 45.588$, alt. 514 m, Pine forest, Rosmarinus, under stones and leaf litter, 28.3.2008. 
General distribution. Caucasus (Armenia, Azerbaijan), Italy (Lampedusa Island), Greece (Milos, Sifnos, Serifos, Gavdos?, Symi, Kastelorizo islands) Morocco, Algeria, Tunisia, Libya, Egypt, Turkey, Israel, Jordan, Lebanon, Syria, Iran, Saudi Arabia, Yemen, Turkmenistan, Uzbekistan, Tajikistan, Kazakhstan (Würmli 1980, Negrea 1997, Lewis and Wranik 1990, Simaiakis and Mylonas 2008).

Distribution in Tunisia (Map 1). A widespread and much more common species than S. morsitans, in particular in central and southern Tunisia. In the North it is known only from Korba on the Cap Bon Peninsula. In the central and southern regions of the country it occurs in the High tell (hills of Le Kef), virtually along the whole Tunisian Ridge (from Chambi to Zaghouan mountains), the eastern lowland plain (the so called Sahel) and the plain of Jeffara (Matmata Mts., Tataouine region), the islands Djerba and Kerkennah. In the West it is found from the High Steppes (Gafsa Mts.) down to the Sahara boundaries (Oriental Erg). In the past the species has been reported also from Adjel el Haioum, Arad, Sfax, Savoual, Makuassy, B. el Aalia, Jebel Cherchera, Gabes, Gabes-Mensel, Oasis Gafsa, Kairouan and Tunis (Verhoeff 1891, Pocock 1892, Silvestri 1896, Brölemann 1904, Turk 1955, Dobroruka 1968, Würmli 1980). We were unable to find some of the localities, e.g. Adjel el Haioum, Arad, Savoual, Makuassy, B. el Aalia, Gabes-Mensel, and they are not marked on the map.

Altitudinal range in Tunisia. From sea level up to $1500 \mathrm{~m}$ in the mountains (surroundings of Chambi Peak). In Saudi Arabia it is reported up to $2400 \mathrm{~m}$ alt. (Lewis 1986).

Habitats. Oak forests dominated by Quercus ilex or Q. coccifera; coniferous forests of Pinus halepensis; heterogeneous woods with $Q$. ilex and $P$. halepensis; semidry areas dominated by Acacia raddiana; coastal areas with sparse shrubs and semihumid grasslands; maquis with Olea europaea, Pistacia lentiscus; dry grasslands; dry rocky hills; sandy deserts; suburban areas; agricultural lands; Olea europaea stands; oases dominated by Phoenix dactylifera.

Remarks. The morphology of the specimens examined corresponds well to the species' description given by Attems (1930), Würmli (1980), Lewis (1986), Zalesskaja and Schileyko (1991). All records of the closely related S. oraniensis and S. clavipes from Tunisia (e.g. Pocock 1892, Silvestri 1896, Turk 1955) are erroneous and should be attributed to this species. While there are no reliable records of the latter in North Africa at all, S. oraniensis is known from few localities in Algeria and Morocco, as well as from the Maltese Archipelago (Würmli 1980, Zapparoli et al. 2004) and its occurrence in Tunisia is not improbable.

\section{Scolopendra morsitans Linnaeus, 1758}

Figs 8-13

Scolopendra morsitans: Attems 1902, Sitzungsberichte der Kaiserlichen Akademie der Wissenschaften in Wien, Mathematisch-Naturwissenshaftliche Classe 111 (I): 561.

Scolopendra morsitans scopoliana: Kraepelin 1903, Mitteilungen aus dem Naturhistorischen Museum in Hamburg, 20: 253. 
Scolopendra morsitans and S. morsitans scopoliana: Brölemann 1904, Bulletin du Muséum d'Histoire Naturelle 6: 320-321.

Scolopendra morsitans and S. morsitans scopoliana: Brolemann 1921, Bulletin de la Société des Sciences Naturelles du Maroc, I (3-6): 104.

Scolopendra morsitans and S. morsitans scopoliana: Attems 1930, Das Tierreich, 54: 23-25, figs 38-39. Scolopendra morsitans and S. morsitans scopoliana: Brolemann 1932, Bulletin de la Société d'Histoire Naturelle d'Afrique du Nord, 23 (2): 51-52.

Scolopendra morsitans: Dobroruka 1968, Revue de Zoologie et de Botanique Africaines 78(3-4): 203. Scolopendra amazonica: Lewis 1969, Zoological Journal of the Linnaean Society, 48 (1): 49-57.
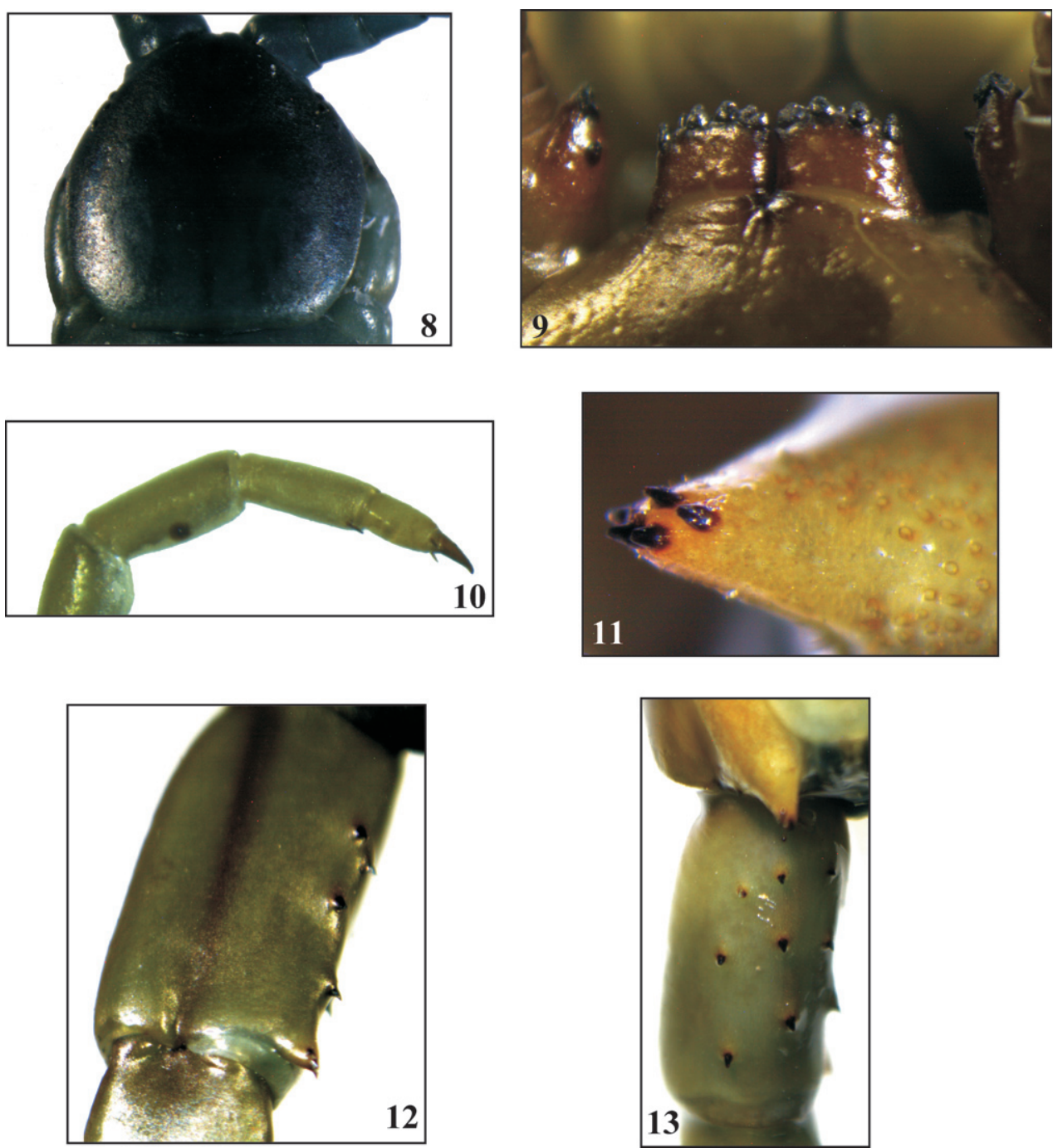

Figs 8-I3. Scolopendra morsitans: 8 - head plate; 9 - forcipular coxosternal toothplate and trochanteroprefemoral process; 10 - leg 1; 11 - coxopleural process, ventral view; $12-13$ - prefemur of ultimate leg, dorsal and ventral views, respectively. 
Material examined. 2 ex., Nabeul Distr., Jebel Abderrahman, N36 41.31/ E10 40.20 , alt. $168 \mathrm{~m}$, garrigue with Cistus monspeliensis, Pistacia lentiscus, Lavandula sp., 2428.11.2004; 1 ad., Siliana, N3605.17/ E09²1.53, alt. 427 m, 7.6.2005; 1 ex., Zaghouan Distr., Jebel El Oust, N36 33.32/ E10 03.38, alt. 75 m, March 2006; 1 juv., Zaghouan Distr., Jebel El Fahs, N36 22.39/ E09 53.41 , alt. 172 m, 20.3.2006; 1 ad., Cap Bon Peninsula, Nabeul Distr., El Haouaria, the ancient Roman quarry and surroundings, $\mathrm{N} 37^{\circ} 03.448 / \mathrm{E} 10^{\circ} 59.869$, alt. $51 \mathrm{~m}$, slope facing the sea, under stones, 24.3.2008.

General distribution. North America (USA, Mexico); Caribbean Islands; South America; Atlantic Ocean Islands; Europe; Africa; Arabian Peninsula; Southeast Asia (incl. Indonesia, New Guinea, Philippines, Taiwan, and Japan); Indian Ocean Islands (Comoro Islands, Madagascar, Mascarene Islands, Seychelles); India; Australia; New Zealand; Pacific Islands (for more detailed information, see Shelley et al. 2005).

Distribution in Tunisia (Map 2). Known from the Subhumid and Semiarid bioclimatic zones. Comparatively rare species, found in northeastern Tunisia only - Cap Bon Peninsula, Jebel Zaghouan, Jebel El Fahs and near Siliana. The species has been reported also from Medjez-el-Bab (Attems 1902), Tunis and its surroundings (Brölemann 1904) and Jebel Serdj (Dobroruka 1968).

Altitudinal range in Tunisia. Known from sea level up to approx. $600 \mathrm{~m}$.

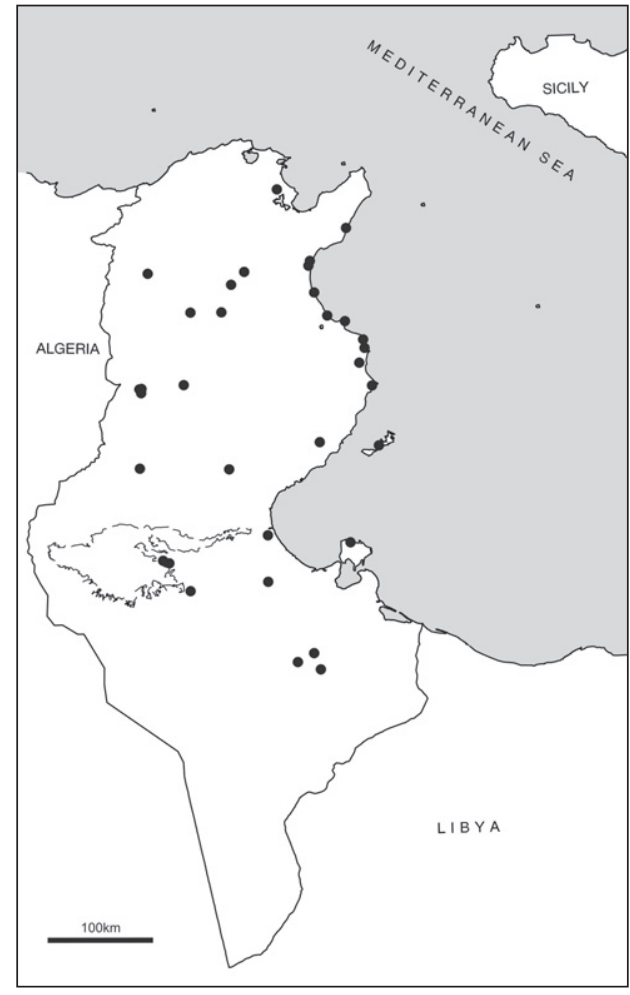

Map I. Distribution of S. canidens in Tunisia.

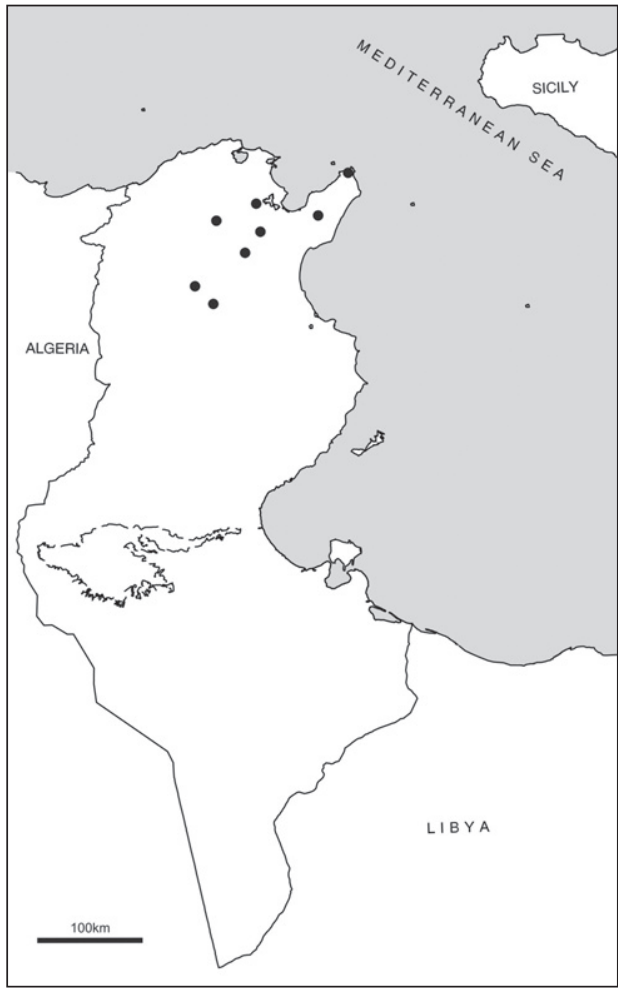

Map 2. Distribution of $S$. morsitans in Tunisia. 
Habitats. Coniferous forests dominated by P. halepensis, mixed woods of $Q$. coccifera and Rosmarinus officinalis; garrigue with Cistus monspeliensis, Pistacia lentiscus, Lavandula sp.; also found in open coastal areas.

Remarks. All the specimens examined have olive green-blackish colouration, which is characteristic for S. morsitans scopoliana C.L. Koch, 1841. However, Lewis $(1969,1978)$ studied the variation of African scolopendrid centipedes, and particularly that of $S$. amazonica and stated that the colouration show a considerable degree of variation, thus being an unreliable taxonomic character. Koch (1982) observed the same variability in $S$. laeta in Australia, finding some correlation with the rainfall. The darkest forms of $S$. laeta occur mainly in areas with high mean annual rainfall (more than $750 \mathrm{~mm}$ ), although sometimes they are also found in regions with low rainfall (up to $250 \mathrm{~mm}$ ). Other characters used to characterize $S$. m. scopoliana are tergal margination starting on tergite 17 , and coxopleural process bearing 5 spines (Brolemann 1932). As it has already been shown by Lewis (1969) these are also of little taxonomic value in $S$. morsitans and for this reason $S$. morsitans scopoliana is here considered a junior synonym of $S$. morsitans.

\section{Cormocephalus gervaisianus (C.L. Koch, 1841)}

Figs $14-17$

Cupipes gervaisianus: Silvestri 1896, Naturalista Siciliano, An. I, (Nuova Serie), 8: 151.

Cupipes gervaisianus: Kraepelin 1903, Mitteilungen aus dem Naturhistorischen Museum in Hamburg, 20: 179, fig. 120.

Cupipes gervaisianus: Attems 1908, Voyage zoologique en Khroumirie (Tunisie), Rouen: 104. Cupipes gervaisianus: Brolemann 1921, Bulletin de la Société des Sciences Naturelles du Maroc, I (3-6): 104.

Cormocephalus gervaisianus: Attems 1930, Das Tierreich, 54: 102, figs 121-122.

Cupipes gervaisianus: Brolemann 1932, Bulletin de la Société d'Histoire Naturelle d'Afrique du Nord, 23 (2): 50.

Cormocephalus gervaisianus: Dobroruka 1968, Revue de Zoologie et de Botanique Africaines 78(3-4): 204.

Material examined. 1 ex., Tunis Distr., Faculty of Sciences of Tunis, N36 41.31 / E10 40.20 , alt. $81 \mathrm{~m}$, urban area with scattered trees of Eucalyptus, Acacia mimosa and Nerium oleander, 24.9.2003; 3 ex., same locality, 29.9.2003; 3 ex., same locality, 15.10.2003; 1 ex., same locality, January 2004; 2 ex., Beja Distr., Nefza, N36 88 / E9 ${ }^{\circ}$ 03, garrigue with Olea europaea, Pistacia lentiscus, 27.2.2004; 2 juv., same locality, 18.4.2004; 1 juv., same locality, 3.10.2005; 2 ex., Jendouba Distr., Feidja N.P., $\mathrm{N} 36^{\circ} 29.76 / \mathrm{E} 08^{\circ} 18.36$, alt. $746 \mathrm{~m}$, oak forest dominated by Quercus faginea with scattered Q. suber and a dense underwood of Erica arborea, Phillyrea angustifolia, Cystus trifolia and Calycotome villosa, 7.3.2004; 1 ex., Jendouba Distr., Col des Ruines Ain Draham, N36 $47.24 /$ E08 41.02 , alt. 799 m, oak forest dominated by $Q$. faginea associated with scattered Q. suber, 18.4.2004; 1 ex., Bizerta Distr., Ichkeul 
N.P., N3708.30/ E0941, alt. 51 m, 7.1.2005; 6 ex., same locality, 8.2.2004; 2 juv., same locality, 24.9.2005; 1 ex., same locality, 3.12.2006; 2 ex., Sousse Distr., Bou Ficha, N36 $17.55 / \mathrm{E} 10^{\circ} 27.30$, alt. $6 \mathrm{~m}$, open area with scattered shrubs, 22.3.2005; 1 ex., Ariana Distr., Jebel Ammar, Sidi Thabet, N3655.05/ E1004.54, alt. 70 m, maquis with scattered crops of Olea europaea, Callitris articulata and Lavandula multifida, 20.11.2003; 1 ex., same locality, 6.10.2006; 1 ex., Bizerta Distr., Zouaouine, N37 $07.49 /$ E10 04.09, alt. 5 m, 11.1.2004; 1 juv., Tunis Distr., Jebel Rsas, N36³7.22/ E10²0.15, alt. 600 m, 21.9.2005; 1 ex., Le Kef, N36¹1.44/ E08 44.39, alt. 831 m, 27.4.2005; 2 ex., Ariana Distr., El Ghazela, N36 53.32/ E10¹0.62, alt. 14 m, houses' garden, 13.04.2007; 1 ex., Jendouba Distr., Beni Mtir, 19.2.2007, alt. 500 m; 1 juv., Tunis Distr., Jebel Bou Kornine, 17.2.2004; 3 juv., Zaghouan Distr., Jebel Zaghouan, N36²3.269/ E1008.157, alt. 352 m, 25.2.2007; 1 ex., Ariana Distr., El Ghazela, house's garden, 20.3.2008; 4 ad., 2 juv., Tunis Distr., Bou Kournine N.P., N36 42.530/ E10²0.680, alt. 105-150 m, Thuya, Eucalyptus/ dry river bed, under stones and logs, 4.3.2008; 1 ad., 1 juv., Zaghouan Distr., Jebel Zaghouan, surroundings of the Gouffre du Courant d'Air (small limestone cave), N36²1.980/ E1005.513, alt. $561 \mathrm{~m}$, Quercus ilex, Pistacia lentiscus, Jasminum fruticans, under stones and leaf litter, 17.3.2008; 3 ad., same mountain, surroundings of the marabout Sidi Bou Gabrine, $\mathrm{N} 36^{\circ} 22.423 / \mathrm{E} 10^{\circ} 06.328$, alt. $642 \mathrm{~m}$, meadows, scattered trees, under stones and
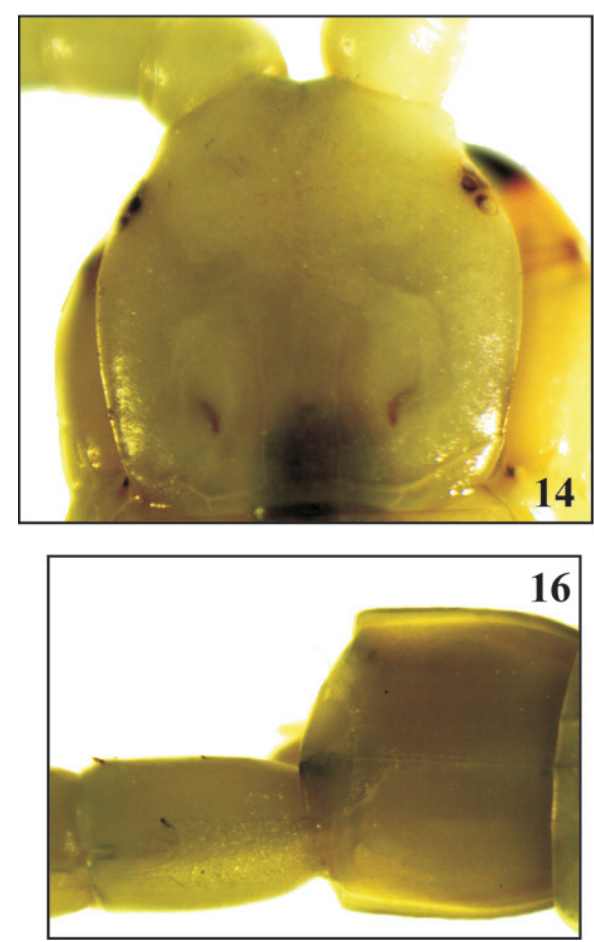
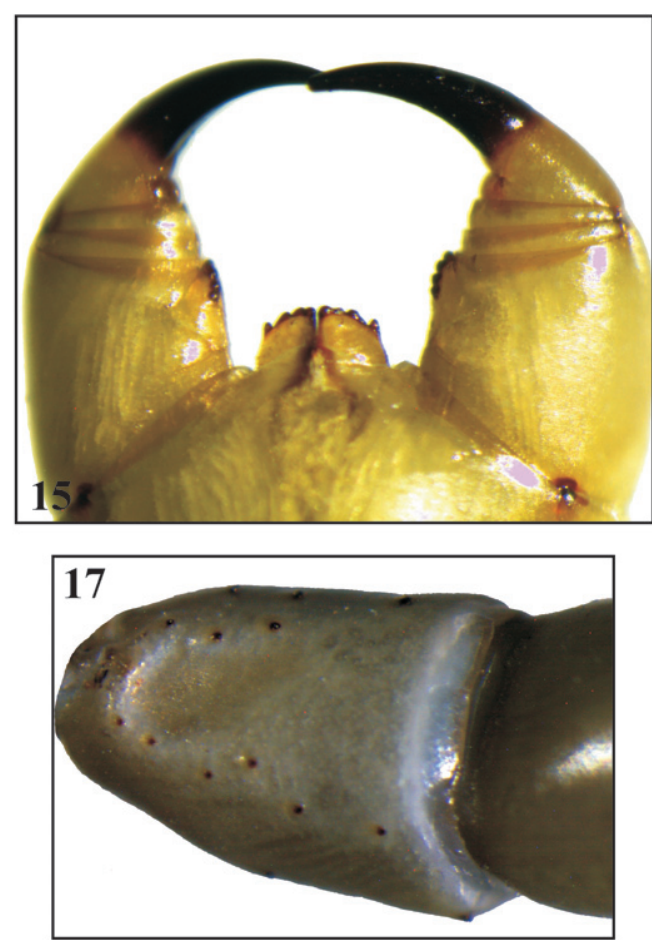

Figs I4-I7. Cormocephalus gervaisianus: 14 - head plate; 15 - forcipular coxosternum and forcipules; 16 terminal tergite and prefemur of ultimate leg, dorsal view; 17 - prefemur of ultimate leg, ventral view. 
leaf litter, 17.3.2008; 1 juv., same locality, 29.3.2008; 1 ex., same mountain, collecting along the track between Gouffre Anti Prehistorique (N36 21.595/ E10 05.208) and Sidi Bou Gabrine (N36 $22.423 /$ E10 06.328$)$, 500-700 m, mixed forest, under stones and leaf litter, 18.3.2008; 3 ad., same mountain, collecting along the track Sidi Bou Gabrine (N36 $22.423 /$ E10 06.328) - Sidi Abdel kader Cave (N36 22.419/ E10 06.371) - Saida Mannoubia (N36 22.650/ E10 06.332) - the asphalt road to Zaghouan $\left(36^{\circ} 22.924 / \mathrm{E} 10^{\circ} 06.789\right)$, alt. $650-780 \mathrm{~m}$, mixed forest, under stones and leaf litter, 19.3.2008; 5 ad., 4 juv., Beja Distr., 7 km of Zahret Medine, N36 $46.857 /$ E09 ${ }^{\circ} 01.688$, alt. $500 \mathrm{~m}$, limestone hill, shrubs, under stones, 20.3.2008; 1 ad., 1 juv., same district, $13 \mathrm{~km}$ of Nefza (road Tabarka-Nefza), N36 57.610/ E08 56.507 , alt. 150 m, Pine forest, under stones, 23.3.2008; 2 ad., 3 juv., Jendouba Distr., Tabarka, the Genoese fort and surroundings, N36 57.838 / E08 44.680 , alt. 20-30 m, slope facing the sea, grass, rocks scattered trees, under stones and logs, 22.3.2008; 1 ad., same district, Hammam Bourguiba (west of Ain Draham), N36²5.926/ E08 35.084, alt. 158 m, meadow with scattered trees, under stones, 22.3.2008; 2 ad., Cap Bon Peninsula, Nabeul Distr., near Oued El Abid Dam, N36²9.901/ E10²2.378, alt. 42 m, grass, stones, under stones, 24.3.2008; 3 ad., Zaghouan Distr., Jebel Mansour, close to Sidi Aouidet Village, N36 $12.307 /$ E09 45.588 , alt. 514 m, Pine forest, Rosmarinus, under stones and leaf litter, 28.3.2008.

Description. Colour yellowish to olive-green. Maximal length, including ultimate legs, ca. $60 \mathrm{~mm}$. Head plate with 2 paramedian sutures occupying the posterior half of head plate (Fig. 14). Antennae composed of 17 articles, the basal 6 glabrous. Tooth plate with $3+1$ teeth, the lateralmost one well separated from the others. Trochanteroprefemoral process moderately expanded bearing 4 tubercles (Fig. 15). Legs 1-20 with two spurs on tarsus 2. Spiracles small and rounded. Tergites 1-20 with 2 paramedian sulci (those on first tergite not reaching anterior border), tergite 21 with a complete median suture. Sternites 2 to 20 with two complete paramedian sutures which are well separated anteriorly and posteriorly and narrowing in the middle of sternite. Sternite 21 trapeziform, broader anteriorly. Ultimate pair of legs: coxopleuron with one lateral spine and long and slender process bearing 2 terminal spines; pores not reaching posterior border of coxopleura. The length of coxopleural process varies considerably between specimens. Prefemur, femur and tibia strongly swollen with dorsal furrow, tarsus 1 wider than tarsus 2 ; prefemur with 2 ventrolateral rows of 3-5 spines, and 8-10 ventromedial and medial teeth and 2-6 dorsomedial ones (Figs 16-17). Pretarsus finely serrated ventrally, longer than tarsus 2.

General distribution. Spain, Algeria, Tunisia, Azerbaijan (Minelli 2006)

Distribution in Tunisia (Map 3). Widespread in North and Central Tunisia. The range covers the Mogods-Kroumirie Mts. in the west (Feidja, Beni Mtir) and spreads to the eastern part of the Tunisian Ridge (Jebel Mansour and Jebel Zaghouan) and the main coastal area of the Gulf of Tunis (Bizerta, Tunis, Ariana) including the Cap Bon Peninsula (Oued el Abid). Further south it has been found also in the Sahel (Bou Ficha in the district of Sousse). In the past recorded from Tunis, Souk el Arba, Babouch and Ain Draham (Silvestri 1896, Attems 1908). Dobroruka (1968) reported the species from Savoual (Zaghouan Region) but we were unable to find this locality on the map. 
Altitudinal range in Tunisia. Known from sea level up to approx. $800 \mathrm{~m}$.

Habitats. Mixed oak formations dominated by either Quercus faginea or Q. suber, coniferous forests dominated by $P$. halepensis, mixed forests of $Q$. faginea and Q. suber, $Q$. faginea and Pinus pinaster, P. halepensis and Quercus ilex, Q. coccifera and $P$. halepensis. It is also found in semidry open areas, garigue with Olea europaea, suburban habitats and coastal grasslands.

Remarks. The morphological characters of the specimens examined correspond well with the description of this species given by Attems (1930) which was the most recent description. Cormocephalus, which currently comprises about 70 species, was divided into three supergroups, each composed of several species-groups (Schileyko and Stagl 2004). In this tentative division, C. gervaisianus belongs to the gervaisianus species group of supergroup III, which is characterized by the presence of complete (rarely somewhat shortened) paramedian sulci on tergite 1; paramedian sulci complete from tergite 2; prefemur of ultimate leg-pair usually bearing ventrolateral spines; coxa of terminal legs with well developed coxopleural process; and pretarsus of ultimate legs longer than tarsus 2.

\section{Otostigmus spinicaudus (Newport, 1844)}

Figs 18-25

Otostigma tunetanum Verhoeff, 1901, Nova Acta Leopoldina, 77: 433, Vergl. Taf. III Abb. 16.

Otostigmus spinicaudus: Kraepelin 1903, Mitteilungen aus dem Naturhistorischen Museum in Hamburg, 20: 107, fig. 49.

Otostigmus spinicauda: Brolemann 1921, Bulletin de la Société des Sciences Naturelles du Maroc, I (3-6): 104.

Otostigmus spinicaudus: Attems 1930, Das Tierreich, 54: 148, fig. 176.

Otostigmus spinicaudus: Brolemann 1932, Bulletin de la Société d'Histoire Naturelle d'Afrique du Nord, 23 (2): 51.

Otostigmus spinicaudus: Lewis 2000, Journal of Natural History, 34: 434, figs 1-10.

Material examined. 1 ex., Sidi Bouzid Distr., Bou Hedma N.P., N34³0.28/ E09³5.46, alt. 574 m, 20.3.2006; 1 ex., Kasserine Distr., Chambi N.P., surrounding of the park's guest house, N35¹0.139/ E0840.486, alt. 950-1000 m, Pinus halepensis, Stipa tenacissima, Thuya sp., under stones, logs and leaf litter of Pinus halepensis, 8.3.2008; 1 ex., Gabes Distr., Matmata, N3332.450/ E0959.054, alt. 384 m, arid biotope, shrubs and stones, under stones, 13.3.2008.

General distribution. Known from Morocco, Algeria, Tunisia, Libya and the Spanish islands Fuerteventura and Lanzarote (Canary Isl.); O. spinicaudus ghiblanus Manfredi, 1935 and O. spinicaudus latispinus Manfredi, 1939 are known only from their type localities in Libya (Minelli 2006).

Distribution in Tunisia (Map 4). Known from Tunis (Verhoeff 1901), the mountains Bou Hedma and Chambi, and the surroundings of Matmata (new records); the specimen from Matmata may be another (sub)species (see below). 

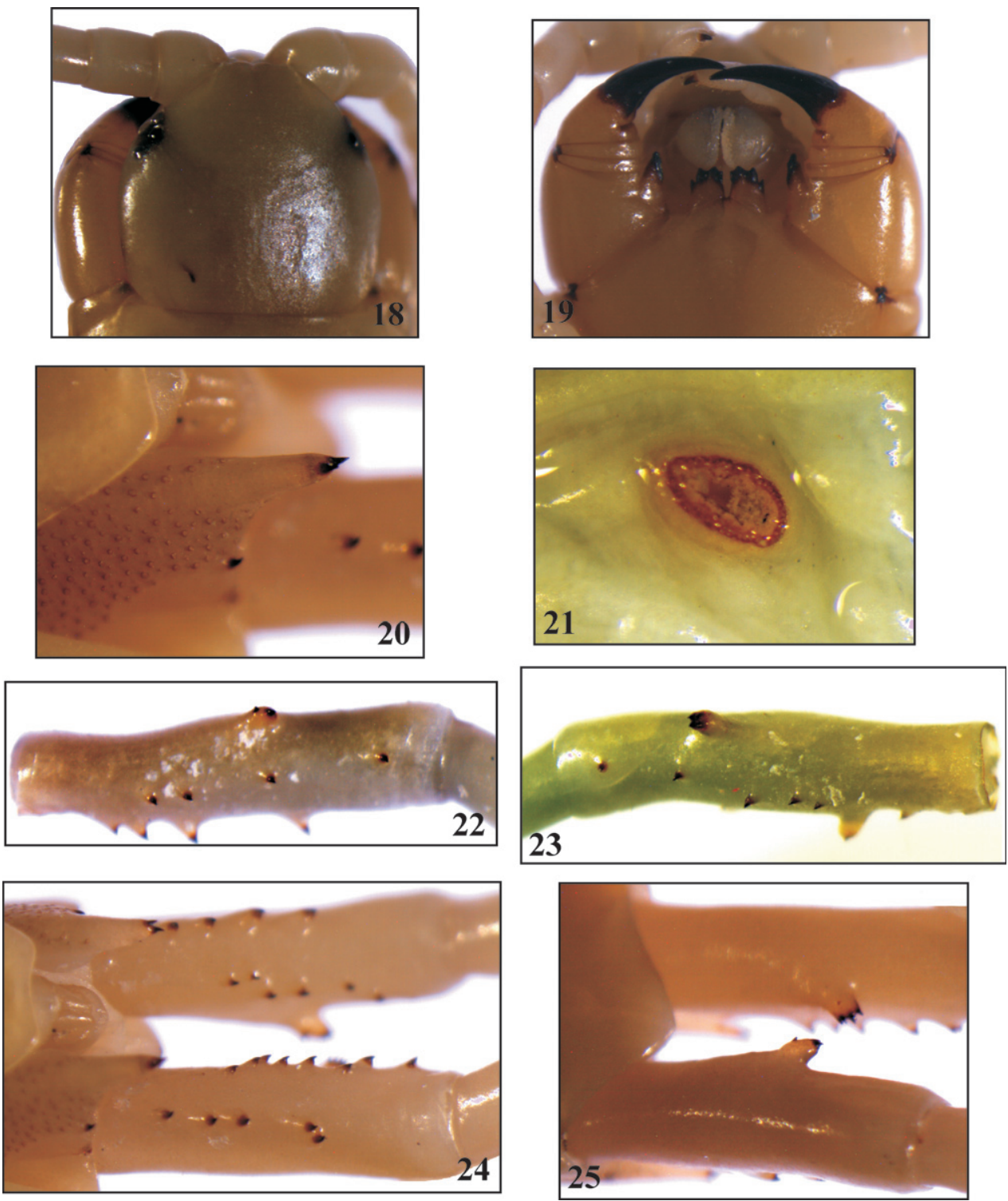

Figs 18-25. Otostigmus spinicaudus: 18 - head plate; 19 - forcipular coxosternum and forcipules; 20 - coxopleural process, lateral view; 21 - spiracle; 22-23 - prefemur of ultimate legs (specimen from Chambi): left leg, ventromesal view; right leg, mesal views, respectively; 24-25 - prefemora of ultimate legs (specimen from Matmata), ventral and dorsal views, respectively.

Altitudinal range in Tunisia. Known from 950-1000 m.

Habitats. Arid biotopes with Acacia raddiana or shrubs; sparse P. halepensis and Thuya forest grown with Stipa tenacissima.

Remarks. Lewis (2000) provided a detailed re-description of $O$. spinicaudus based on material from the Canary Islands. The specimens from Jebel Chambi (Figs 21-23) 
and Bou Hedma correspond well with the description given by Lewis, differing only in the number of ventromedial prefemoral spines on ultimate leg (4 vs. 3). In the specimen from Chambi two tarsal spurs are present on leg-pairs 1-9 the rest to 19 have one, while in the Bou Hedma specimen only legs 1-6 have two tarsal spurs. In the Canary Islands specimens there were usually two tarsal spurs on the first four pairs of legs but sometimes they occurred as far as leg-pair 8. Both specimens have coxopleural processes bearing 2 apical, one lateral and one dorsal spine. The dorsomedial conical protuberance bears a single apical spine in the specimen from Bou Hedma and two to four in the specimen from Jebel Chambi (Figs 22-23).

The specimen from Matmata is differing from the other two specimens and from the Lewis' (2000) redescription in that the prefemur of the ultimate leg bears 4-5 ventrolateral and 6-9 ventromedial spines (vs. 3/3 in Canary specimens and 4/4 in other Tunisian specimens), and the conical protuberance bears 4-5 spines (vs. usually 1-2) (Figs 24-25). In all other respects the specimen resembles O. spinicaudus.

Manfredi $(1935,1939)$ described two subspecies of spinicaudus from Libya - $O$. s. ghiblanus Manfredi, 1935 and O. s. latispinus Manfredi, 1939. The former was separated from nominate form by the presence of incomplete sternal sutures and only 2 apical spines on the coxopleural process, as well as by the different position of the

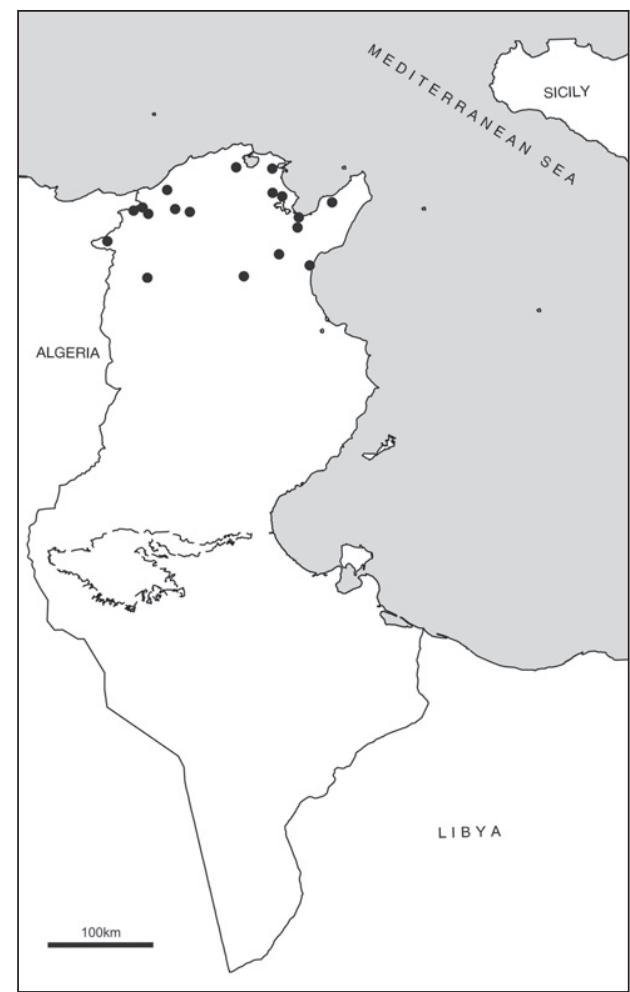

Map 3. Distribution of C. gervaisianus in Tunisia.

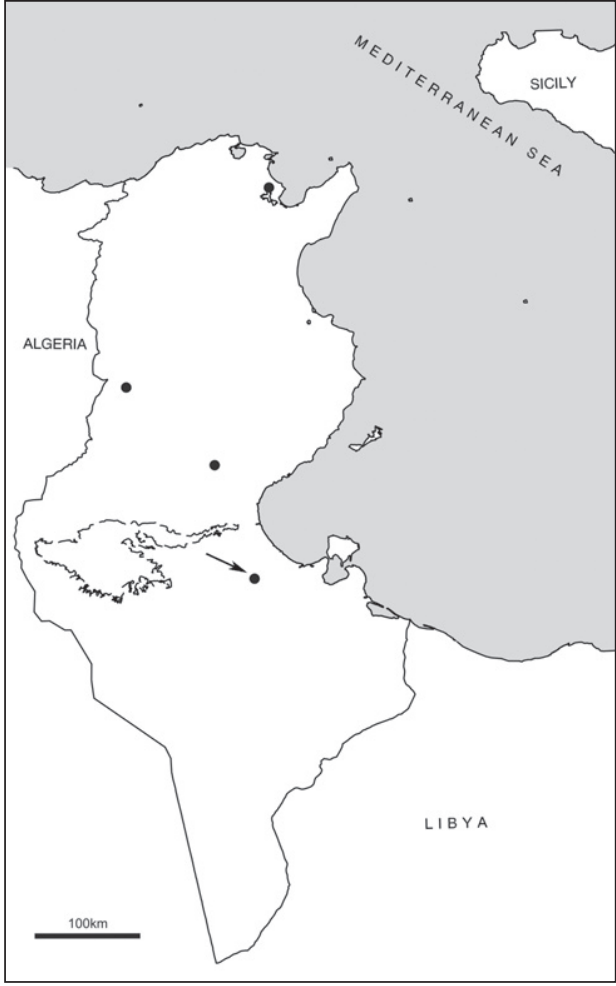

Map 4. Distribution of O. spinicaudus in Tunisia. The Matmata record is marked with an arrow. 
dorsomedial spine on the prefemur of ultimate leg-pair (Manfredi 1935). The subspecies latispinus, was distinguished by the size, shape and the position of the dorsomedial prefemoral protuberance of the ultimate pair of legs, which is sited at mid-length of prefemur (big and emerging as a triangular appendix at the median side of the leg, sometimes bent distad, dorsally convex, ventrally concave with an apical spine). The prefemur also has strong longitudinal medial sulcus. Although not specified, the number of ventral prefemoral spines is higher than that in the type (Manfredi 1939). Having a larger number of prefemoral spines and well-developed conical protuberance on the dorsomedial side of the prefemur, the Matmata specimen resembles $O$. spinicaudus latispinus. However, it has 4-5 apical spines on the dorsomedial prefemoral protuberance instead of 1 , and lacks a longitudinal sulcus. It could be a distinct (sub) species, although with only one specimen available it could represent an aberrant individual. The irregular arrangement of the prefemoral spines and their elevated number may indicate the ultimate legs are regenerated. Further Tunisian and other material is required in order to clarify the situation.

\section{Family Cryptopidae}

\section{Cryptops (Cryptops) trisulcatus Brölemann, 1902}

Figs 26-27

Cryptops anomalans: Silvestri 1896, Naturalista Siciliano, An. I, (Nuova Serie), 8: 151. Misidentification?

Cryptops anomalans: Attems 1908, Voyage zoologique en Khroumirie (Tunisie), Rouen: 104. Misidentification?

Cryptops trisulcatus: Brolemann 1932, Bulletin de la Société d'Histoire Naturelle d'Afrique du Nord, 23 (2): 50.

Material examined. 1 ex., Jendouba Distr., Beni Mtir, N36²4.44/ E0844.52, alt. 500 m, 19.2.2007, alt. 500 m; 1 ex., Nabeul Distr., Soliman, N36 42.54/ E10 21.15, alt. 98 m, 12.11.2006; 1 ex., Jendouba Distr., Ain Draham, Col des ruines, N3647.24/ E08 41.02, alt. 799 m, 5.2.2004; 1 ex., same locality, 3.10.2005; 1 ex., Beja Distr., Jebel El Jouza Amdoun, N3650.09/ E09 06.0, alt. 614 m, mixed oak forest, 19.11.2003; 3 ex., same locality, 4.11.2003; 1 ex., Beja Distr., Nefza, N3645.42/ E09 11.41 , alt. 176 m, 27.2.2004; 1 ex., same locality, 18.4.2004; 2 ex., Bizerta Distr., Ichkeul N.P., 8.2.2004; 1 ex., same locality, 7.1.2005; 1 ex., Ariana Distr., Nahli, N36 ${ }^{\circ} 53.02 /$ E10 09.14 , alt. 75 m, 6.12.2003; 1 ex., Kasserine Distr., inside Chambi N.P., N35¹1.901/ E08 39.505, alt. 1291 m, Pinus halepensis, Quercus ilex, Stipa tenacissima, slope, under stones and leaf litter, 9.3.2008; 1 ex., inside Chambi N.P., N35¹1.709/ E08 39.309, alt. 1286 m, Pinus halepensis, Quercus ilex, Stipa tenacissima, ruins, under stones and leaf litter, 9.3.2008; 2 ex., Zaghouan Distr., Jebel Zaghouan, surroundings of the marabout Sidi Bou Gabrine, N36 22.423/ E10 06.328, alt. $642 \mathrm{~m}$, meadows, scattered trees, under stones and leaf litter, 17.3.2008; 1 ex., same 
locality, 29.3.2008; 1 ex., same mountain, collecting along the track between Gouffre Anti Prehistorique (N36 21.595/ E10 05.208) and Sidi Bou Gabrine (N36 22.423/ $\left.\mathrm{E} 10^{\circ} 06.328\right)$, 500-700 $\mathrm{m}$, mixed forest, under stones and leaf litter, 18.3.2008; 1 ex., same mountain, collecting along the track Sidi Bou Gabrine (N36 22.423/ E10 06.328) - Sidi Abdel kader Cave (N36 22.419/ E10 06.371) - Saida Mannoubia $\left(\mathrm{N} 36^{\circ} 22.650 / \mathrm{E} 10^{\circ} 06.332\right)$ - The asphalt road to Zaghouan (N36 $22.924 /$ E10 06.789), alt. 650-780 m, mixed forest, under stones and leaf litter, 19.3.2008; 1 ex., Beja Distr., 7 km of Zahret Medine, N3646.857/ E0901.688, alt. 500 m, limestone hill, shrubs, under stones, 20.3.2008; 1 ex., Jendouba Distr., 4 km of Tabarka (direction of Malloula), N36 57.476/ E08 43.781, alt. 225 m, Eucalyptus and pine forest, under stones, 22.3.2008; 7 ex., Zaghouan Distr., Jebel Mansour, close to Sidi Aouidet Village, N36 $12.307 /$ E09 45.588 , alt. 514 m, Pine forest, Rosmarinus, under stones and leaf litter, 28.3.2008.

General distribution. Canary Islands, Algeria, Tunisia, Maltese Archipelago, Portugal, Spain (incl. Balearic Islands), South of France (incl. Corsica), Italy (incl. Sicily, Sardinia), Romania, Insular Greece (Ionian, Dodecanese islands and Crete), SE Turkey (Zapparoli 2002, Zapparoli et al. 2004).

Distribution in Tunisia (Map 5). Known from the Humid to Semiarid bioclimatic zones. The species range covers a vast area starting from the Mogods-Kroumirie region in the West and parts of the Tunisian Ridge chain further South (e.g. Chambi N.P.) and ending in Jebel Mansour, Jebel Zaghouan, the Gulf of Tunis and Cap Bon Peninsula (Soliman) area in the northeast. Known also from Ichkeul N.P.

Altitudinal range in Tunisia. Known from approx. 200 up to approx. $1300 \mathrm{~m}$.

Habitats. Forests of Quercus faginea, mixed woods of $Q$. faginea and $Q$. suber, $Q$. coccifera and P. halepensis; P. halepensis and Q. ilex; found also in heterogenous Eucalyptus forest.

Remarks. Although this widespread Mediterranean species has already been recorded from Algeria (Ribaut 1915) and from the neighbouring Italian island of Pantelleria situated approx. $70 \mathrm{~km}$ off the Tunisian coast (Zapparoli 1995), these are the
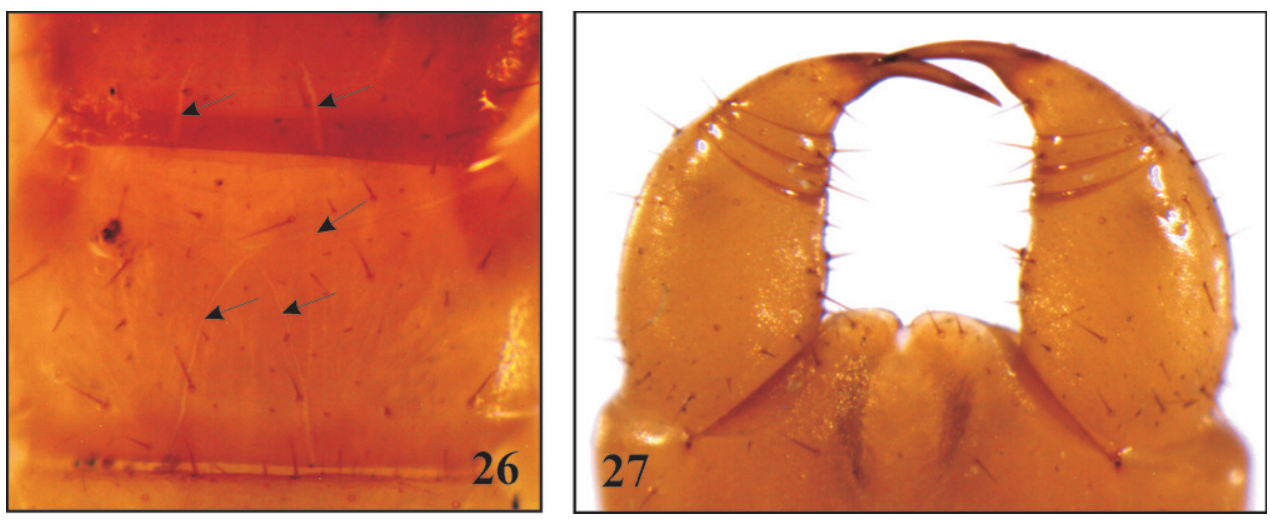

Figs 26-27. Cryptops trisulcatus: 26 - posterior part of head plate and tergite 1;27 - coxosternum. 
first definite records of C. trisulcatus in Tunisia (see also under Discussion). Brolemann (1932) summarized the distribution of $C$. trisulcatus as "Littoral méditerranéen d'Afrique et d'Europe". It remains unclear whether this general statement was supported with original data from Tunisia. The species is also known from the Maltese Archipelago (Zapparoli et al. 2004). In several places, like Jebel Zaghouan, Jebel Mansour, Jebel Chambi, C. trisulcatus is fairly common and occurs syntopically with C. punicus.

\section{Cryptops (Cryptops) punicus Silvestri, 1896}

Figs 28-30

Cryptops anomalans Newport, v. n. punicus Silvestri, 1896, Naturalista Siciliano, An. I (Nuova Serie), 8: 151 .

Cryptops anomalans punicus: Brolemann 1921, Bulletin de Société des Sciences Naturelles du Maroc, I (3-6): 104.

Trigonocryptops punicus: Brolemann 1928, Bulletin de la Société d'Histoire Naturelle de Toulouse, 57: 257, figs 10-18.

Trigonocryptops punicus: Brolemann 1932, Bulletin de la Société d'Histoire Naturelle d'Afrique du Nord, 23 (2): 48-49.

Material examined. TUNISIA: 3 ex., Nabeul Distr., Soliman, N 36² $42.54 /$ E10 21.15 , alt. 98 m, 12.11.2006; 2 ex., Ariana Distr., Sidi Thabet, N36 55.05/ E10 04.54, alt. 70 m, 20.11.2003; 1 ex. Mahdia Distr., Chebba, 20.3.2004; 1 ex., Le Kef, N36¹1.44/ E08 44.39 , alt. 623 m, 24.10.2003; 5 ex., Bizerta Distr., La Grotte Beach, N37 19.56/ E09 ${ }^{\circ}$ 51.30, alt. 39 m, 12.2.2004; 1 ex., Sousse Distr., Bou Ficha, N36 17.55/ E10 27.30, alt. 6 m, 22.3.2005; 4 ex., Zaghouan Distr., Jebel Zaghouan, N36²3.269 / E10 08.157, alt. 352 m, 25.2.2007; 1 ex., Gabes Distr., Chenini Oasis, 22.3.2006; 1 ex., Ariana Distr., Sidi Thabet, 17.3.2004; 1 ex., Kasserine Distr., Chambi N.P., surrounding of the park's guest house, N35¹0.139/ E0840.486, alt. 950-1000 m, Pinus halepensis, Stipa tenacissima, Thuya, under stones, logs and leaf litter of Pinus halepensis, 8.3.2008; 2 ex., Gabes Distr., Matmata, N3332.450/ E09 59.054 , alt. 384 m, arid biotope, shrubs and stones, under stones, 12.3.2008; 2 ex., Mahdia Distr., Mahdia City, Touristic area, $\mathrm{N} 35^{\circ} 32.796 / \mathrm{E} 11^{\circ} 01.662$, alt. $0 \mathrm{~m}$, scattered palm trees and shrubs close to the road, polluted area not far from agricultural land, under stones, 16.3.2008; 2 ex., Zaghouan Distr., Jebel Zaghouan, surroundings of the Gouffre du Courant d'Air (small limestone cave), N3621.980/ E1005.513, alt. 561 m, Quercus ilex, Pistacia lentiscus, Jasminum fruticans, under stones and leaf litter, 17.3.2008; 1 ex., same mountain, surroundings of the marabout Sidi Bou Gabrine, N36²2.423/ E10 06.328, alt. 642 m, meadows, scattered trees, under stones and leaf litter, 17.3.2008; 1 ex., Jendouba Distr., Tabarka, the Genoese fort and surroundings, N36 $57.838 /$ E0 $8^{\circ} 44.680$, alt. $7 \mathrm{~m}$, sea shore, 10 $40 \mathrm{~m}$ from the water line, logs, grass, under stones, 22.3.2008; 1 ex., Nabeul Distr., Cap Bon Peninsula, Kelibia, the fort and surroundings, N36 ${ }^{\circ} 50.337 /$ E $11^{\circ} 06.841$, alt. 1040 m, slope, Eucalyptus, Mimosa, shrubs, under stones, 25.3.2008; 3 ex., same area, 7 $\mathrm{km}$ of Menzel Bou Zelfa, N36 $40.268 /$ E10 40.677 , alt. 236 m, Pinus, Quercus, shrubs, 

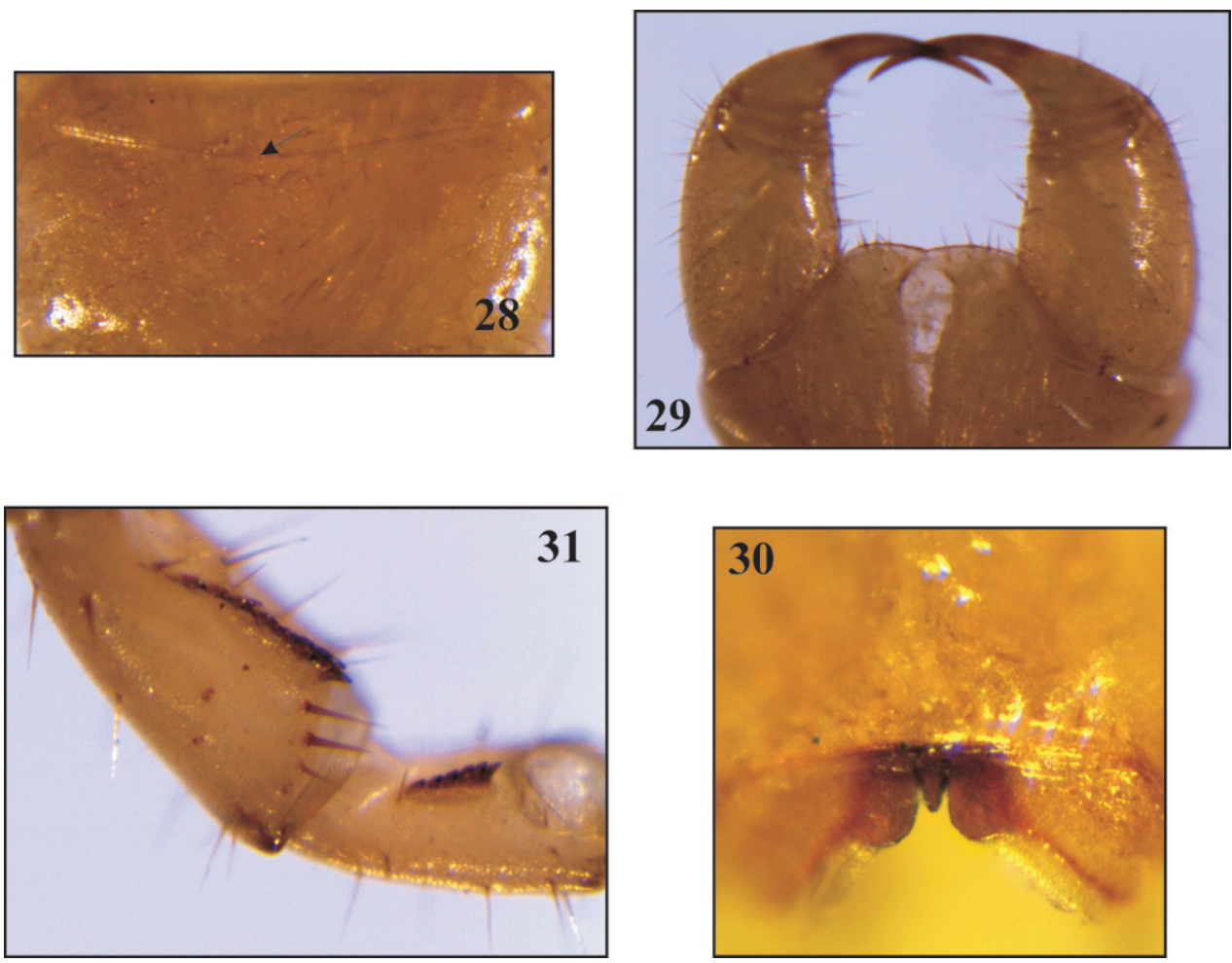

Figs 28-3 I. Cryptops punicus: 28 - tergite 1; 29 - coxosternum; 30 - labral tooth; 31 - tibia and tarsus of ultimate leg. Arrows on figures 26 and 28 indicate the tergal sutures.

under stones, 25.3.2008; 1 ex., Siliana Distr., Jebel Bargou, 5 km of Bargou (road Bargou - Oueslatia), N3605.775/ E09³7.347, alt. 571 m, Quercus, Olea, shrubs, under stones, 28.3.2008; 5 ex., Zaghouan Distr., Jebel Mansour, close to Sidi Aouidet Village, $\mathrm{N} 36^{\circ} 12.307 /$ E09 45.588 , alt. 514 m, Pine forest, Rosmarinus, under stones and leaf litter, 28.3.2008. LIBYA: 1 ex., Tripoli, 0-20 m, 28-30.11.1999, P. Beron leg.

Description. Light brown to tawny with dense punctuation, and extensive setation. Maximal length: 22-28 mm. Head as long as broad, with 2 short paramedian longitudinal sutures on the anterior and posterior borders of head plate. Antenna composed of 17 articles. Coxosternum rounded and slightly prominent (Fig. 29). Labrum with a single tooth (Fig. 30). First tergite with a complete curved anterior transverse suture only (Fig. 28). Paramedian sutures incomplete on the second tergite, becoming complete from the third. Lateral crescentic sulci starting on the 3rd or 4th tergite. From third leg-pair onwards tarsus 1 and tarsus 2 faintly separated. Ultimate pair of legs: coxopleura with pore field extending to but not touching the posterior margin of coxa. Many scattered setae among the pores and a tuft of 7-8 posterior to the pore field. Tibial saw with 11-13 sharp teeth. Tarsal saw with 5-7 teeth (Fig. 31).

General distribution. Algeria, Tunisia, Libya and Italy: Sicily, Sardinia, Tuscan Archipelago (Matic 1962, Minelli 1982, Zapparoli 1995). 
Distribution in Tunisia (Map 6). One of the most common scolopendromorphs in Tunisia found in all bioclimatic zones. Originally described from Tunis (Silvestri 1896), it is currently known also from the littoral of Kroumirie (Tabarka), from the Gulf of Tunis area and along the eastern part of the Tunisian Ridge up to the Cap Bon Peninsula (Soliman, Mensel Bou Zelfa). Towards the centre, it is present in the western mountains of the Ridge (Chambi N.P.) and along the eastern coast of the Sahel (Sousse, Mahdia, Chebba) down to the plain of Jeffara in the southeast (Matmata, Gabes).

Altitudinal range in Tunisia. Known from sea level up to $1000 \mathrm{~m}$ in the mountains (Jebel Chambi).

Habitats. Forests dominated by Q. coccifera or Pinus halepensis, mixed woods of $Q$. ilex and $P$. halepensis or $Q$. coccifera and $P$. halepensis, mountain meadows, suburban areas, oases, arid rocky terrains with scattered shrubs.

Remarks. Silvestri (1896) described Cryptops punicus from Kroumirie as a variety of $C$. punctatus (now anomalans). It was synonymised with $C$. anomalans by Kraepelin (1903) and later revived by Brolemann (1928). Besides raising punicus to full species rank, Brolemann also transferred it to the genus Trigonocryptops, which is currently considered a subgenus of Cryptops Leach, 1815. Trigonocryptops is characterised by trigonal sutures in front of the endosternite, a transverse ridge on the sternites between the coxae, generally bipartite tarsi, head overlying tergite 1 , a transverse suture on tergite

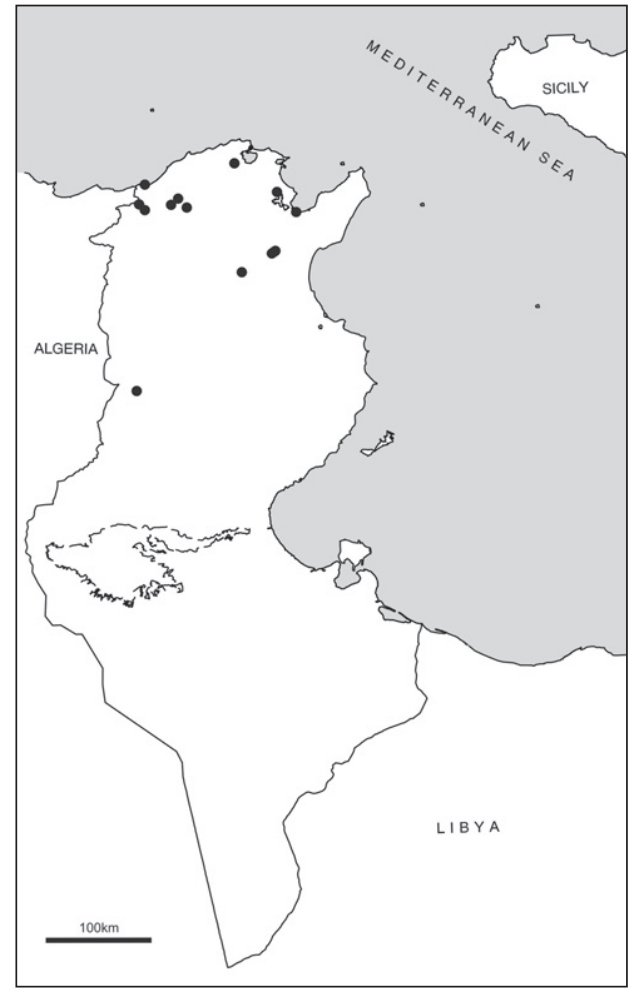

Map 5. Distribution of C. trisulcatus in Tunisia.

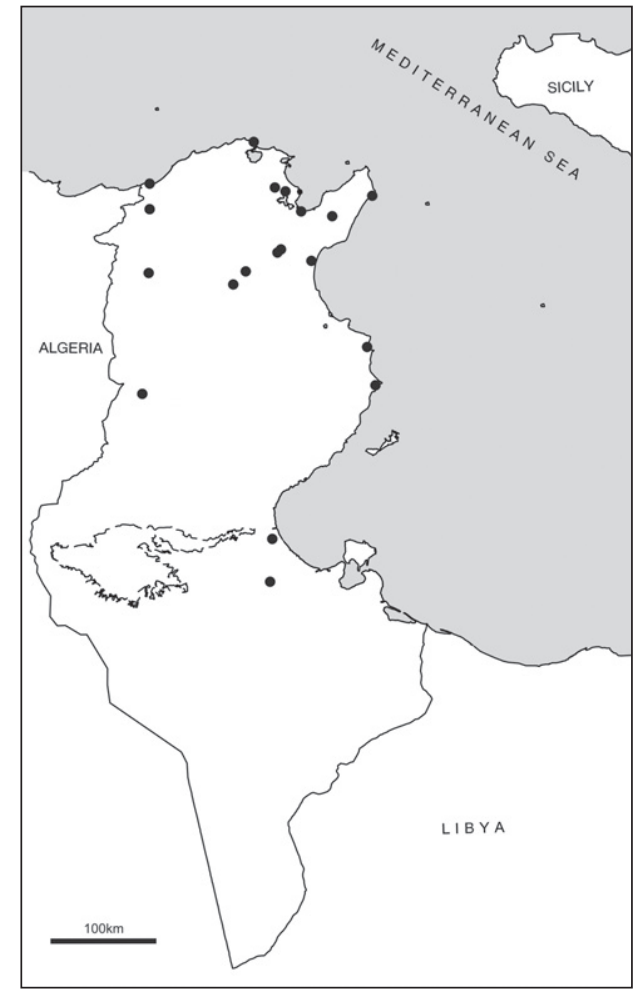

Map 6. Distribution of $C$. punicus in Tunisia. 
1, a divided katopleure and mostly yellow or brown colour. Other characters shared by members of Trigonocryptops are an anterior setose area on the clypeus delimited by sutures, paired spinose process on the ultimate leg, slit-like spiracles, etc. (Edgecombe 2005). C. punicus shows some of the characters typical for Trigonocryptops, e.g. subdivided tarsi (very faint in most specimens), yellowish colouration, head overlying tergite 1 , transverse suture on tergite 1 but these are shared with some species of the subgenus Cryptops. Instead of trigonal sutures at the base of endosternite there is just a curved transverse suture (see Brolemann 1928, fig. 14). With this possible exception C. punicus lacks the characters unique to the subgenus Trigonocryptops viz. the clypeus is devoid of sutures, and ultimate leg is devoid of processes. The spiracles are ovoid-shaped and the katopleure is single. For the above reasons, we prefer to place $C$. punicus in the subgenus Cryptops rather than in Trigonocryptops as suggested by Brolemann (1928). Nevertheless, until combined morphological and molecular phylogenetic analysis is undertaken in the genus Cryptops, the real position of $C$. punicus remains uncertain. The specimen from Tripoli represents the first formal record of the species from Libya.

\section{Discussion}

\section{Remarks on the occurrence of Scolopendra cingulata, S. oraniensis and C. anomalans in Tunisia}

Scolopendra cingulata, S. oraniensis and C. anomalans were reported for Tunisia in several old publications but were not found in the recently collected material. While those of $S$. oraniensis (e.g. Silvestri 1896, Brölemann, 1904) are most likely due to misidentification with the closely related S. canidens (see also Würmli 1980), the presence of the other two species requires further explanation in the light of the new study. S. cingulata was reported for all the countries of the Maghreb region in Brolemann's checklist of North African myriapods (1921). This publication still serves as a main source of information regarding the North African myriapod fauna, being cited even nowadays in papers outlining the world distribution of $S$. cingulata (e.g. Zapparoli 2002, Zapparoli et al. 2004, and Simaiakis and Mylonas 2008). It seems that Brolemann's data originated from Kraepelin's (1903) general statement that $S$. cingulata is distributed "durch ganz Nordafrika" [throughout northern Africa], though the author did not list exact localities to support this. There are numerous later records of $S$. cingulata from one or another country in the Maghreb (e.g. Verhoeff 1908, Manfredi 1939, Brolemann 1947), and the species was also reported to occur on the closely situated to Tunisia islands Pantelleria and Lampedusa (Zapparoli 1995). However, until new material becomes available to confirm its presence in Tunisia, we regard the old records as dubious. So far, the only reliable records of $S$. cingulata in North Africa come from the eastern part of Egypt (Lewis 1985, Minelli 2006).

Cryptops anomalans was recorded by Silvestri (1896) from Souk el Arba, Ain Draham and Babouch, and by Attems (1908) from Ain Draham. The recent intensive collecting in the region of Ain Draham where all these localities are situated did not 
confirm its presence there. Instead, another species, $C$. trisulcatus, appeared to be quite common in the area. Taking into account that $C$. trisulcatus superficially resembles $C$. anomalans (both having identical number of saw teeth on ultimate leg-pair and tergite 1 having obvious sutures), and the fact that at the time when Silvestri reported anomalans, C. trisulcatus had not been described, it is very probable that Silvestri misidentified his material. This may also holds true for Attems' later record of anomalans.

\section{Distribution patterns}

The scolopendromorph centipedes are widely distributed in Tunisia and occur in all the bioclimatic zones - from the humid and subhumid forests in the northwestern part of the country to the pure sandy deserts in the south. Cryptops punicus and S. canidens are the most common species, and except for the extreme south are virtually distributed throughout the country. The notable absence of $S$. canidens from the Kroumirie region and the core of Cap Bon Peninsula, could be explained by the higher humidity in those areas and possible competition with S. morsitans. The recent finds of S. canidens from Ksar Oued Soltane and Douiret (both situated south of Tatauine) constitute the southernmost point of distribution of Scolopendromorpha in Tunisia and together with still unidentified specimen of Lithobiidae represent the southernmost record of Myriapoda as a whole. The records from the Hoggar (Ahaggar Mts., Southern Algeria) represent the southernmost records of S. canidens in Africa (Würmli 1980).

$S$. morsitans has a restricted distribution in northeastern Tunisia from the extreme northern parts of Cap Bon Peninsula to the surroundings of Siliana. It seems that $S$. canidens and $S$. morsitans occur allopatrically in the country, the latter being generally restricted to more humid parts, the former to the rest of the country, including the harsh deserts in the south, southern coastal regions, and the islands of Djerba and Kerkennah. The eastern part of Tunisian Ridge is a possible contact zone where they may occur together. Cryptops trisulcatus and Cormocephalus gervaisianus show an almost identical distribution in north and central Tunisia, with the exception that the former goes farther south reaching the Chambi N.P. Cryptops trisulcatus is absent from the Cap Bon Peninsula although it is found along the coast to the west of that area. $O$. spinicaudus is the rarest of all the six species. Until now it was known only from Tunis, while the freshly collected material comes from three localities lying well apart from each other in the central and southeastern parts of the country.

\section{Habitat preferences}

In Tunisia, scolopendromorphs are known from virtually all the main types of vegetation, starting with the humid and subhumid oak forests of Quercus faginea and Q. suber in the Kroumirie-Mogods Mts., passing through the subhumid coniferous forests of the Tunisian Ridge and ending in the pure sandy desert of Sahara. They are also known 
in suburban and urban areas, in close proximity to the littoral zone and in agricultural stands. Caves are a largely unexplored biotope in terms of scolopendromorphs. It is not improbable that cave-dwelling species will be found in future in such a large limestone massifs as Jebel Zaghouan.

Cryptops punicus is a eurytopic species, which occurs in forests (oak, pine, eucalyptus, etc.), coastal areas, open grasslands, oases, agricultural stands and arid rocky areas with scattered shrubs. S. canidens is also quite euryecious, absent only in the oak forests of Kroumirie. It was found in oak forests dominated by Q. ilex (Jebel Bargou, Makthar) or Q. coccifera (Jebel Chambi); coniferous forests of P. halepensis (Le Kef) and heterogeneous woods with $Q$. ilex and P. halepensis; semidry areas dominated by Acacia raddiana (Bou Hedma N.P.); coastal areas with sparse shrubs and semihumid grasslands; dry grasslands; dry rocky hills (Jebel Bou Ramli, Gafsa); pure sandy deserts (Douz); suburban areas (e.g. Tataouine and Mahdia cities); agricultural lands; Olea europaea stands (the Sahel); oases dominated by Phoenix dactylifera (Kebili). S. canidens is the only myriapod species in Tunisia recorded in pure sandy desert. Having studied material from Israel, Negrea (1997) concluded that " $S$. canidens is a thermophilous, eurythermic and xerophilous species, occurring on low altitudes (-370 m at 'En Gedi)" and "come from sites.....Judean Hills, Judean Desert, Dead Sea, central Negev, and Arava Valley, the most arid parts within the investigated area".

Like the preceding species, Otostigmus spinicaudus is also a thermophilic species. It was found under stones in arid and semidesert biotopes with Acacia raddiana (Bou Hedma N.P.) and shrubs (Matmata). In Jebel Chambi it was collected in a sparse $P$. halepensis and Thuya forest grown with Stipa tenacissima. Lewis (2000) reported it from a crater on Lanzarote. Scolopendra morsitans has hitherto been registered only in coniferous forests of Pinus halepensis, mixed woods of Quercus coccifera and Rosmarinus officicnalis and in open coastal areas. Cormocephalus gervaisianus and C. trisulcatus show an affinity to the forest biotopes, being often present in old oak formations and different kinds of mixed heterogeneous woods.

\section{Key for identification of the scolopendromorph centipedes of Tunisia}

1(2) with 4 ocelli on each side of cephalic plate (Family Scolopendridae) .............. 3

2(1) Head without ocelli. Ultimate legs with saw teeth on tibia and tarsus 1 (Family Cryptopidae) 9

3(4) Legs without tarsal spurs, pretarsus of ultimate leg longer than tarsus 2, spiracles very small...................................................... Cormocephalus gervaisianus

4(3) Most legs with tarsal spurs, pretarsus of ultimate leg markedly shorter than

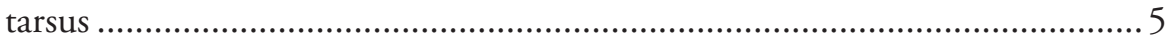

5(6) First spiracle (of leg-bearing segment 3) oval (Fig. 21), the rest round Otostigmus spinicaudus

6(5) Spiracles triangular (Fig. 4), more or less parallel to body axis 7 
7(8) Leg 1 with two tarsal spurs (Fig. 3); coxopleural process generally long, with at least six spines sited laterally as well as distally (Fig. 5); prefemur of ultimate leg with two rows of spines ventrolaterally and two ventromedially (Fig. 7)

S. canidens

8(7) Leg 1 with one tarsal spur (Fig. 10); coxopleural process short, with at most five distal spines, none laterally (Fig. 11); prefemur of ultimate leg with, at most, three rows of three spines ventrally (Fig. 13); femur and sometimes tibia in males flattened with ridged lateral and median edges S. morsitans

9(10) Tergite 1 with anterior transverse suture from which run two diverging sutures to the posterior border of the tergite (Fig. 26) C. trisulcatus

10(9) Tergite 1 with anterior transverse suture only (Fig. 28)...................... C. punicus

\section{Acknowledgements}

The collecting trip in Tunisia in March 2008 was financially supported by the Field Museum Collection Fund. We are grateful to Petra Sierwald (Chicago, USA) for arranging the grant. N.A. is deeply obliged to Willi Xylander (Görlitz, Germany) for supporting her research visit to the SMNG in 2008, to Said Nouira and to Mohamed Hedi Ktari (Tunis, Tunisia) for their overall support. Henrik Enghoff (Copenhagen, Denmark) provided copies of some old papers. Atef Belkahla and Houda Belghagi (Tunis, Tunisia) kindly helped with the preparation of maps. Two anonymous referees provided valuable comments on the manuscript.

\section{References}

Attems C (1902) Myriopoden von Kreta, nebst Beiträgen zur allgemeinen Kenntnis einiger Gattungen. Sitzungsberichte der Kaiserlichen Akademie der Wissenschaften in Wien, Mathematisch-Naturwissenshaftliche Classe 111 (I): 527-614; 3 t.

Attems C (1908) Note sur les Myriapodes recueillis par M. Henri Gadeau de Kerville en Khroumirie et description de deux espèces et d'une variété nouvelles provenant de cette région de la Tunisie. In: Gadeau de Kerville H. (Ed.). Voyage zoologique en Khroumirie (Tunisie), Rouen: 103-116.

Attems C (1930) Myriopoda. 2. Scolopendromorpha. Das Tierreich. De Gruyter, Berlin 54, 308 pp.

Brölemann H (1904) Catalogue des scolopendrides des collections du Muséum d'Histoire Naturelle de Paris (Collection du Muséum déterminée par M. le professeur Karl Kraepelin, et collection H. W. Brölemann). Bulletin du Muséum d'Histoire Naturelle 6: 316-324.

Brolemann H (1921) Liste des Myriapodes signalés dans le nord de l'Afrique. Bulletin de Société des Sciences Naturelles du Maroc I (3-6): 99-110.

Brolemann H (1928) Notes sur quelques Cryptops. Bulletin de la Société d'Histoire Naturelle de Toulouse 57: 249-260. 
Brolemann H (1932) Tableaux de détermination des Chilopodes signalés en Afrique du Nord. Bulletin de la Société d'Histoire Naturelle d'Afrique du Nord 23 (2): 31-64.

Brolemann H (1947) Catalogue des Myriapodes chilopodes de la collection de l'Institut Scientifique Chérifien. Bulletin de la Société des Sciences Naturelles du Maroc 25-27: 172-182.

Cloudsley-Thompson J (1956) Studies in diurnal rhythms. VI. Bioclimatic observations in Tunisia and their significance in relation to the physiology of the fauna, especially woodlice, centipedes, scorpions and beetles. Annals and Magazine of Natural History ser. 12, vol. 9: 305-329.

Dobroruka L (1968) Myriapoda-Chilopoda aus der Sammlung des Musée Royal de l'Afrique Centrale. Revue de Zoologie et de Botanique Africaines 78(3-4): 201-215.

Edgecombe G (2005) A troglomorphic species of the centipede Cryptops (Trigonocryptops) (Chilopoda: Scolopendromorpha) from Western Australia. Records of the Western Australian Museum 22: 315-323.

Koch L (1982) Taxonomy of the centipede Scolopendra laeta Haase (Chilopoda: Scolopendridae) in Australia. Zoological Journal of the Linnaean Society 76: 125-140.

Koch L (1983) Morphological Characters of Australian Scolopendrid Centipedes, and the Taxonomy and Distribution of Scolopendra morsitans L. (Chilopoda: Scolopendridae: Scolopendrinae). Australian Journal of Zoology 31: 79-91.

Kraepelin K (1903) Revision der Scolopendriden. Mitteilungen aus dem Naturhistorischen Museum in Hamburg 20: 1-276.

Lewis J (1969) The variation of the centipede Scolopendra amazonica in Africa. Zoological Journal of the Linnean Society 48 (1): 49-57.

Lewis J (1978) Variation in Tropical Scolopendrid Centipedes: Problems for the Taxonomist. Abhandlungen und Verhandlungen des Naturwissenschaftlichen Vereins in Hamburg (N.F.) 21/22: 43-50.

Lewis J (1985) Possible species isolation mechanisms in some scolopendrid centipedes (Chilopoda; Scolopendridae). Bijdragen tot de Dierkunde 55 (1): 125-130.

Lewis J (1986) Centipedes of Saudi Arabia. Fauna of Saudi Arabia 8: 20-30.

Lewis J (2000) Variation in three centipede species of the genus Otostigmus and its bearing on species discrimination (Chilopoda; Scolopendromorpha; Scolopendridae). Journal of Natural History 34: 433-448.

Lewis J, Wranik W (1990) On the centipedes of Yemen. Zoology of Middle East 4: 61-70.

Lewis J, Edgecombe G, Shelley R (2005) A proposed standardised terminology for the external taxonomic characters of the Scolopendromorpha (Chilopoda). Fragmenta Faunistica 48 (1): $1-8$.

Manfredi P (1935) Alcuni Chilopodi della Tripolitania. Atti della Società Italiana di Scienze Naturali 74: 419-422.

Manfredi P (1939) Miriapodi della Libia. Bollettino dei Musei di Zoologia e Anatomia Comparata della R. Università di Torino 47: 109-120.

Matic Z (1962) Beiträge zur Kenntnis der Chilopoda aus Sizilien. Bollettino delle sedute dell'Accademia Gioenia di Scienze naturali in Catania Serie IV, 7: 51-62.

Minelli A (1982) On Sardinian centipedes. Bollettino di Zoologia 49: 1-16. 
Minelli A (ed.) (2006) CHILOBASE. A web resource for Chilopoda taxonomy. http://chilobase.bio.unipd.it

Negrea S (1997) On the Scolopendromorpha (Chilopoda) of Israel and adjoining areas. Israel Journal of Zoology 43: 279-294.

Pocock R (1892) On the Myriapoda and Arachnida collected by Dr. Anderson in Algeria and

Tunisia. Proceedings of the Zoological Society of London: 24-28.

Ribaut H (1915) BiospeologicaXXXVI. Notostigmophora, Scolopendromorpha, Geophilomorpha

(Myriapoda) (1 re série). Archives de zoologie expérementale et générale 55 (6): 323-346.

Schileyko A, Stagl V (2004) The collection of scolopendromorph centipedes (Chilopoda) in the

Natural History Museum in Vienna: a critical re-evaluation of former taxonomic identifications. Annalen des Naturhistorischen Museums in Wien 105B: 67-137.

Shelley R, Edwards G, Chagas A Jr (2005) Introduction of the centipede Scolopendra morsitans L., 1758, into Northeastern Florida, the first authentic North American record, and a review of its global occurrences (Scolopendromorpha: Scolopendridae: Scolopendrinae). Entomological News 116 (1): 39-58.

Silvestri F (1896) Una escursione in Tunisia (Symphyla, Chilopoda, Diplopoda). Naturalista Siciliano An. I, (Nuova Serie) 8: 144-161.

Simaiakis S, Mylonas M (2008) The Scolopendra species (Chilopoda: Scolopendromorpha: Scolopendridae) of Greece (E-Mediterranean): a theoretical approach on the effect of geography and palaeogeography on their distribution. Zootaxa 1792: 39-53.

Turk F (1955) The Myriapoda of Dr. Cloudsley-Thompson's expedition to the Tunisian desert. Annals and Magazine of Natural History 12 (8): 277-284.

Verhoeff K (1891) Über einige nordafrikanische Chilopoden. Berliner entomologische Zeitschrift 36: 65-70.

Verhoeff K (1893) Ueber einige palaearktische Chilopoden. Berliner entomologische Zeitschrift 38: 313-326.

Verhoeff K (1901) Zur vergleichenden Morphologie, Systematik und Geographie der Chilopoden. (Beiträge zur Kenntnis paläarktischer Myriopoden 16). Nova Acta Leopoldina 77: 369-465.

Verhoeff K (1908) Über Chilopoden und Isopoden aus Tripolis und Barka, gesammelt von Dr. Bruno Klaptocz. - Zoologischen Jahrbüchern, Abteilung für Systematik 26: 257-284, I Taf.

Würmli M (1975) Systematische Kriterien in der Gruppe von Scolopendra morsitans Linné, 1758 (Chilopoda, Scolopendridae). Deutsche Entomologische Zeitschrift (N. F.) 22: 201-206.

Würmli M (1980) Statistische Unterschungen zur Systematik und postembryonalen Entwicklung des Scolopendra canidens Gruppe (Chilopoda: Scolopendromorpha). Sitzungsberichte der Österreichischen Akademie der Wissenschaften 189: 315-353.

Zalesskaja N, Schileyko A (1991) The scolopendromorph centipedes (Chilopoda, Scolopendromorpha). Nauka Publ. House, Moscow, 102 pp. [In Russian]

Zapparoli M (1995) Chilopoda. In: Massa, B. (ed.): Arthropoda di Lampedusa, Linosa e Pantelleria. Naturalista Siciliano 19 (Suppl.): 115-140.

Zapparoli M (2002) Catalogue of the centipedes from Greece (Chilopoda). Fragmenta entomologica, Roma 34 (1): 1-146.

Zapparoli M, Minelli A, Schembri P (2004) The centipedes of the Maltese Archipelago (Chilopoda). Revue suisse de Zoologie 111 (2): 433-456. 